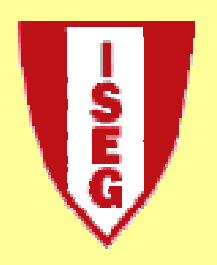

School of Economics and Management

TECHNICAL UNIVERSITY OF LISBON

Department of Economics

António Afonso \& João Tovar Jalles

\title{
Linking Investment and Fiscal Policies
}

WP 16/2011/DE/UECE

Working PAPERS

ISSN Nº 0874-4548

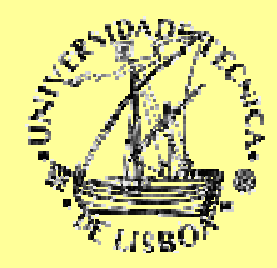




\title{
Linking Investment and Fiscal Policies ${ }^{*}$
}

\author{
António Afonso ${ }^{\text {\# }}$ and João Tovar Jalles ${ }^{+}$
}

July 2011

\begin{abstract}
We assess the relevance of budgetary components for private and public investment using data for a panel of 95 countries for the period 1970-2008, and accounting for the usually encountered econometric pitfalls. Our results show a positive effect attributed to total government expenditures and to public investment in fostering private investment, and negative effects of government expenditure on wages and government consumption spending on private investment. Interest payments and subsidies have a negative effect on both types of investment (particularly in the emerging economies sub-group). Social security spending has a negative effect on private investment for the full and OECD samples, whereas government health spending has a positive and significant impact on private investment.
\end{abstract}

JEL: C23, E62, H50

Keywords: budgetary decomposition, panel analysis, causality, non-linearities, fiscal-rules

\footnotetext{
The authors are grateful to participants in an ECB seminar for useful comments. Part of the research was conducted while João Tovar Jalles was visiting the ECB whose hospitality was greatly appreciated. The opinions expressed herein are those of the authors and do not necessarily reflect those of the ECB or the Eurosystem.

\$ ISEG/UTL - Technical University of Lisbon, Department of Economics; UECE - Research Unit on Complexity and Economics. UECE is supported by FCT (Fundação para a Ciência e a Tecnologia, Portugal), email: aafonso@iseg.utl.pt.

\# European Central Bank, Directorate General Economics, Kaiserstraße 29, D-60311 Frankfurt am Main, Germany. email: antonio.afonso@ecb.europa.eu.

${ }^{+}$University of Cambridge, Faculty of Economics, Sidgwick Avenue, Cambridge CB3 9DD, United Kingdom, email: jodstj2@cam.ac.uk.
} 


\section{Introduction}

Investment is key to economic growth. In fact, the theories of investment dating back to Keynes (1936), first called attention to the existence of an independent investment function in the economy. It is important to distinguish between private and public investment, particularly as similar arguments could also apply to the latter and, perhaps more interestingly, public investment may have differentiated (or at least unclear) effects on growth. ${ }^{1}$

Regarding the determinants of publicly funded investment little research has been conducted. This lack of analysis is especially surprising, as in a great majority of countries throughout the world productive government services have declined as percentage of GDP since the 1970s. Several hypothesis have been put forward to explain the downtrend in public investment, including, extensive privatisation and the drive toward a smaller economic role of the state in the past two or three decades; the emergence of alternative ways to finance infrastructure investment (public-private partnerships); and, in the EU, the impact of the EMU's fiscal rules. According to Mehrotra and Valila (2006), these hypotheses can be refuted. Privatisation is unlikely to have affected public investment as any investment undertaken by public enterprises is recorded in national accounts as investment of the enterprise sector. Secondly, it is also unlikely that any political drive toward a smaller economic role for the state has been very important; after all, regardless of the measure used, governments have not become smaller in recent decades. ${ }^{2}$ Finally, public-private partnerships remain a new and residual phenomenon in most advanced countries.

Against this background, it appears that there remain gaps in our understanding of the determinants of investment (and public in particular). ${ }^{3}$ All in all, fragmented studies cannot be combined into a coherent investment theory. To fill some of the gaps, we employ a crosssection time series analysis (due to the absence of reliable microdata) and aim notably at assessing which budgetary components have been driving (or determine) private and public investment.

With this in mind, we use cross-sectional/time series data for a large panel of developed and developing countries for the period 1970-2008. In the empirical estimations we use

\footnotetext{
${ }^{1}$ Nelson and Singh (1994) looking at 70 developing countries (Low Income Countries and Middle Income Countries) for two distinct time periods (1970-79; 1980-89) and find that the effects of public investment on growth are mixed.

${ }^{2}$ See Afonso and Jalles (2011a) for a recent theoretical and empirical analysis on the - negative - impact of government size on macroeconomic performance.

${ }^{3}$ Even though econometric evidence (Beddies, 1999; Ghura and Hadjimichael, 1996; Ghura, 1997) indicates that, all in all, private investment has a stronger, more favourable effect on growth rather than government or public investment, probably because private investment is more efficient and less closely associated with rentseeking activities and corruption.
} 
growth specifications and address several of the econometric caveats that usually plague such empirical work: outliers, simultaneity, endogeneity, cross-sectional dependence, causality, nonlinearities and threshold effects. Specifically, we examine the following issues: the influence of budgetary components on private and public investment levels; the relevance of different government debt and budget deficit ratios thresholds for the determinants of investment; the robustness of the results to different econometric specifications and between country groups; the existence of panel Granger causality; and the relevance of numerical fiscal rules for government investment in the EMU?

The contributions of our paper to the literature include: i) the assessment of the budgetary determinants of private and public investment with a diversified variety of methods, providing sensitivity and robustness and dealing notably with model uncertainty; ii) the study of the relevance of economic and functional government expenditure categories and of revenue subcomponents; iii) panel Granger causality tests, and the assessment of the existence of crosssectional dependence within homogeneous groups of countries.

In a nutshell, our results comprise notably of the following:

1. Population growth has a positive impact on both types on investment, whereas, in general, initial GDP per capita hampers investment. The age structure of a country also affects investment: for private investment a higher dependency ratio has a negative impact, whereas for public investment the effect is reversed.

2. Each government revenue component (when introduced individually) does not significantly affect private or public investment in OECD countries. However, taxes on income, profits and capital gains as well as social security contributions have a statistically significant positive impact on public investment for the full sample and emerging economies.

3. Decomposing government expenditures, we get that interest payments and subsidies have a negative effect on both types of investment (particularly in the emerging economies sub-group).

4. Regarding functional government spending, social security spending has a statistically negative effect on private investment, whereas government health spending appears with a positive and significant coefficient for private investment.

5. Non-linearities in deficit or debt in percentage of GDP matter for public investment but not that much for private investment levels.

6. Cross-sectional dependence regressions suggest that government revenues have a detrimental effect on private investment, and the reverse is true for public investment. 
7. Granger causality tests find evidence supporting causality running for GDP to private investment and the reverse appears to be stronger (with both positive short and longrun effects).

8. We also find statistically significant negative coefficients on the overall EU fiscal rule index and the budget balance rule index, meaning that although better fiscal numerical rules constrains government spending, it also decreases the amount of capital available for public investment in the EU countries.

The paper is organised as follows. Section two briefly reviews the related literature on the determinants of investment. Section three describes the analytical and econometric methodology. Section four presents the data and discusses our main results. Section five concludes.

\section{Related literature}

The theoretical literature on private investment is quite rich and diverse. ${ }^{4}$ Moreover, there is a large literature on the determinants of private investment in both developed ${ }^{5}$ and developing ${ }^{6}$ countries and two explanations for this interest can be put forward. First, most empirical studies have found positive, significant and robust effect of increases in investment ratio on economic growth (see Figure 1 for a stylised illustration). ${ }^{7}$ Indeed, Levine and Renelt (1992) and Sala-i-Martin (1997) and Sturm and De Haan (2000) found that the ratio of total investment to GDP is among a few variables that are robustly correlated with growth for a diverse group of countries. This raises the question as of why the investment ratios across countries differ so much. Second, debt crises in the early 1990s triggered the interest in the "debt overhang" hypothesis. In general, those studies have found support for the adverse effects of the debts service and debt overhang on private investment. ${ }^{8}$

\footnotetext{
${ }^{4}$ The accumulation of real fixed capital stock and capital formation by the private sector has been prominent in formal models based on the experience of developed countries. The major strands of investment behaviour could be classified as the simple accelerator theory, the liquidity theory, expected profits theory, Tobin's Q theory, and neoclassical theory. For a detailed review of the theoretical literature on investment see Jorgenson (1971) and Clark (1979).

${ }^{5}$ Empirical tests of the neoclassical accelerator theory (Jorgenson, 1967) using data from several advanced economies have been widely applied (Jorgenson, 1971 and Bischoff, 1971).

${ }^{6}$ Studies conducted for Africa, Asia and Latin America have also established the critical linkage between investment and growth. See, Hernandez-Cata, 2000; Ndikumana, 2000; Ben-David, 1998; Chari et al., 1997; Barro and Lee, 1994; Collier and Gunning, 1999; Barro, 1995; Ghura and Hadjimichael, 1996; Khan and Reinhart, 1990; Kormendi and Meguire, 1985.

${ }^{7}$ See, e.g., Ghura (1995), Savvides (1995), De Gregorio (1991), Barro (1991), Khan and Kumar (1993) and Khan and Reinhart (1990).

${ }^{8}$ See, e.g., Solimano (1989), Borensztein (1990), Green and Villanueva (1991), Ozler and Rodrik (1992), Cardoso (1993), Larrain and Vergara (1993), Serven and Solimano (1993), Sakr (1993) and Oshikoya (1994).
} 
Figure 1: Scatter plots of private and public investment against GDPpc growth

(a)

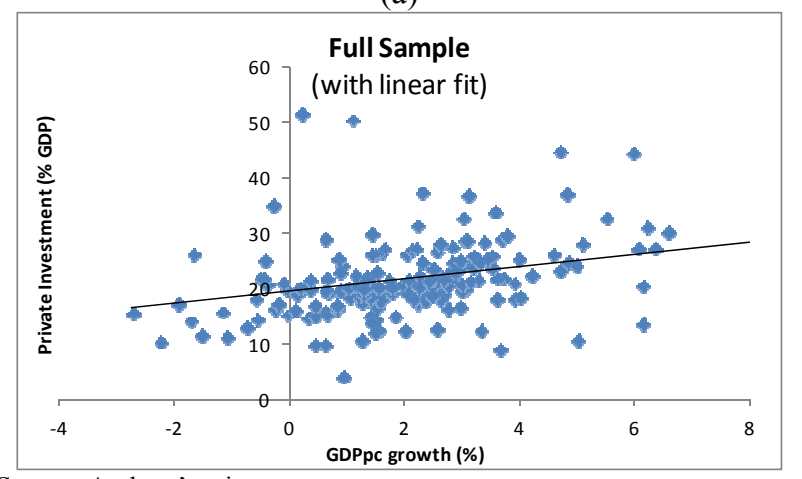

(b)

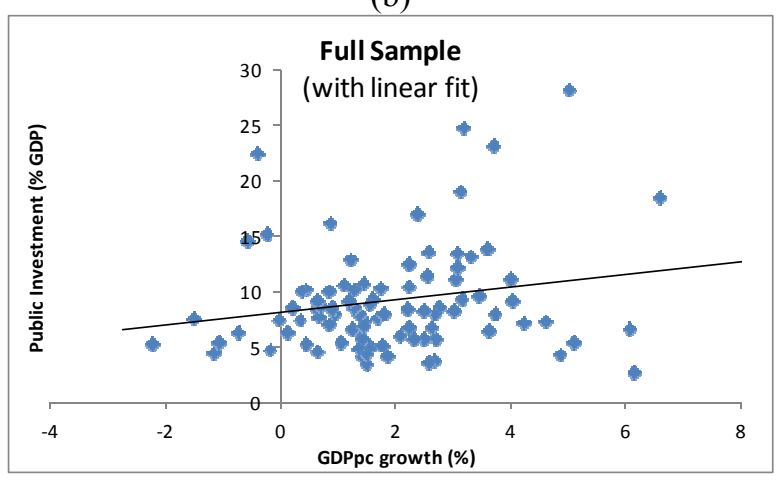

Note: This Figure shows a scatter between the growth rates of GDP per capita against private investment (\% GDP). There seems to be a positive relationship between both types of investment and per capita GDP growth. For the OECD sub-group the positive relationship is stronger (not shown).

When it comes to public investment one would expect it to boost growth. However, on the one hand, higher public investment raises the national rate of capital accumulation above the level chosen (in a presumed rational fashion) by private sector agents. Therefore, public capital spending may crowd-out private expenditures on capital goods on an ex-ante basis as individuals seek to re-establish an optimal inter-temporal allocation of resources. ${ }^{9}$ On the other hand, public capital - particularly infrastructure capital as highways, water systems, sewers and airports - is likely to bear a complementary relationship with private capital in the private production technology. ${ }^{10}$ Thus, higher public investment may raise the marginal productivity of private capital and thereby crowd-in private investment and positively affect output growth in net terms (see Afonso and St. Aubyn, 2009). In Devarajan et al. (1996) (using a sample of developing countries) and Afonso and Furceri (2010) (for advanced countries) government investment has a sizeable negative and statistically significant effect on growth. ${ }^{11}$

Only a handful of studies analyse the determinants of public investment. Except for De Haan et al. (1996) and Sturm (1998) who focus on political-economic factors affecting public investment, estimating a range of model specifications for 22 OECD countries between 1980$92^{12}$ and, more recently, the European Commission (2003) and Turrini (2004) for the EU, ${ }^{13}$

\footnotetext{
${ }^{9}$ As there is a finite limit for domestic savings, public investment can in some cases pose a severe constraint for private investment and would crowd out private investment (Balassa, 1988).

${ }^{10}$ Empirical studies (Bljer and Khan, 1984; Greene and Villanueva, 1991) on 23 countries have shown that public investment in physical infrastructure is complementary to private investment.

${ }^{11}$ Prichett (1996) suggests the so-called "white-elephant" hypothesis in which public investment in developing countries is often used for unproductive and inappropriate projects.

${ }^{12}$ They conclude that episodes of "fiscal stringency" and frequent changes of government are associated with lower public investment and that movements in the latter then to follow private investment.

${ }^{13}$ They find that public investment (as percentage of GDP) tends to decline with GDP, with an improvement in the cyclically adjusted budget balance and with increasing public debt.
} 
there are, to the best of our knowledge, no panel studies explaining government capital spending. More recently, Gali and Perotti (2003) focus on whether the EMU has changed the cyclical behaviour of public investment. They find it to be only "mildly pro-cyclical".

Finally, the empirical literature on the determinants of investment behaviour is roughly divided in two strands. On the one hand, cross-section/time series analyses for one or several countries: Loungani and Rush (1995), Blomstrom et al. (1996), Everhart and Sumlinski (2001), Campos and Nugent (2003) and Krishna et al. (2003) are the main references. On the other hand, microeconometric studies using firm level data: see, e.g., Chirinko and Schaller (1995), Bloom et al. (2001) and Butzen et al. (2002).

\section{Methodology}

\subsection{Analytical framework}

In order to assess the impact of different budgetary sub-components on private and public investment, we estimate two specifications:

$$
\begin{aligned}
& I 1: \text { privinv }=\alpha_{i t}+\beta_{0} y_{i 0}+\beta_{1} Z_{i t}+\gamma F_{i t}+\eta_{t}+v_{i}+\varepsilon_{i t} \\
& I 2: \text { pubinv }=\alpha_{i t}+\beta_{0} y_{i 0}+\beta_{1} Z_{i t}+\gamma F_{i t}+\eta_{t}+v_{i}+\varepsilon_{i t}
\end{aligned}
$$

where priinv, pubinv represent the levels of private and public investment, respectively, and $y_{i 0}$ is the initial value of the real GDP per capita. $Z_{i t}$ is a vector of control variables; $F_{i t}$ is a vector of budgetary component(s) of interest, either from the expenditure or revenue side); $v_{i}$, $\eta_{t}$ correspond to the country-specific fixed effect and time-fixed effect, respectively. Finally, $\varepsilon_{i t}$ is a column vector of some unobserved zero mean white noise-type satisfying the standard assumptions. $\alpha, \beta_{0}, \beta_{1}, \gamma$ are unknown parameter vectors to be estimated. $Z^{1}{ }_{i t}$ includes labour force participation rate, and population growth. Implicit and contingent liabilities represent other factors related to public expenditures (or the need to collect more revenue), but not taken into account so far. For the ageing-related burden, we account for it using the age dependency-ratio, measured as a share of the working age population, depratio_wa, as an explanatory variable in (1) and (2).

\subsection{Econometric approaches}

\section{Model Selection}

It is well known that the inclusion of particular control variables in a given regression can wipe out (or change the signs of) any bivariate relationship (Easterly and Rebelo, 1993) and it 
is necessary to consider which information to include in such regressions as control variables. Therefore, we deal with model uncertainty on the determinants of private and public investment, prior to conducting the main econometric analysis.

We employ the Bayesian Model Averaging (BMA) approach. Essentially BMA treats parameters and models as random variables and attempts to summarise the uncertainty about the model in terms of a probability distribution over the space of possible models. More specifically, the method is used to average the posterior distribution for the parameters under all possible models, where the weights are the posterior model probabilities. To evaluate the posterior model probability the BMA uses the Bayesian Information Criteria (BIC) to approximate the Bayes factors that are needed to compute the posterior model probability, as discussed in more detail in Raftery (1995), Sala-i-Martin et al. (2004) and Malik and Temple (2009). In the empirical section, the output of the BMA analysis includes the posterior inclusion probabilities for variables and a sign certainty index. ${ }^{14}$ The higher the posterior probability for a particular variable the more robust that determinant for investment appears to be.

\section{Panel Techniques}

Cross-country regressions are usually based, in this context, on average values of fiscal and investment variables over long time periods. Drawbacks, problems and inefficiencies due to the discarding of information on within-country variation have been extensively discussed. Resorting to panel data can overcome (some of) these problems, and has other advantages. We focus mainly on combined cross-section time-series regressions using cumulative 5-year non-overlapping averages to smooth the effects of short-run fluctuations. We run within fixed-effects as a benchmark model (for completeness) despite being aware of the econometric IV-related problems. We include time dummies which is consistent with (underlying) common technical progress.

\section{Bias and endogeneity}

Panel data estimations may yield biased coefficient estimates when lagged dependent variables are included. Therefore, we also estimate our regressions using the bias-corrected least-squares dummy variable (LSDV-C) estimator by Bruno (2005).

\footnotetext{
${ }^{14}$ For posterior inclusion probabilities greater than 0.50 , a sign certainty index rather than sign certainty probability is presented, clearly suggesting the relationship being either positive or negative.
} 
Moreover, we use a panel Instrumental Variable-Generalised Least Squares (IV-GLS) approach, which is then complemented by estimating the main equations using Generalised Methods of Moments (GMM), which can be viewed as a step-by-step approach, First by writing down a static model, and then by reformulating it as a dynamic model (partial adjustment model in the case of the convergence regression with initial per capita GDP or the lagged level depending on the dataset). The first-differenced GMM estimate can be poorly behaved if the time series are persistent. This problem can get very serious in practice and authors like Bond, Hoeffler and Temple (2001) suggest the use of a more efficient GMM estimator, the system estimator, to exploit stationary restrictions.

Hence, we estimate the investment equation by system-GMM ${ }^{15}$ (SYS-GMM) which jointly estimates the equations in first differences, using as instruments lagged levels of the dependent and independent variables, and in levels, using as instruments the first differences of the regressors. As far as information on the choice of lagged levels (differences) used as instruments in the difference (level) equation, as work by Roodman (2009) has indicated, when it comes to moment conditions more is not always better. The GMM estimators are likely to suffer from "overfitting bias" once the number of instruments approaches (or exceeds) the number of groups/countries. In the present case, the choice of lags was directed by checking the validity of different sets of instruments and we rely on comparisons of first stage R-squares; alternatively. Intuitively, the system GMM estimator does not rely exclusively on the first-differenced equations, but exploits also information contained in the original equations in levels.

\section{Panel Granger causality}

We also perform a panel version of a Granger-causality test between private (and public) investment and real per capita GDP, similarly to Huang and Temple (2005). ${ }^{16}$

Since causality can run in either direction, we cannot treat say real per capita GDP as strictly exogenous. Alternatively, we run partial adjustment specifications which allow feedback by means of sequential moment conditions to identify the model (see Arellano, 2003). The standard approach in the literature would be to specify an AR(1) model as follows:

\footnotetext{
$\overline{15}$ The GMM aproach estimates parameters directly from moment conditions imposed by the model. To enable identification the number of moment conditions should be at least as large as the number of unknown parameters. Moreover, the mechanics of the GMM approach relates to a standard instrumental variable estimator and also to issues such as instrumental validity and informativeness.

${ }^{16}$ These authors applied the same technique to study the trade-finance relationship in a panel of heterogeneous countries.
} 


$$
\begin{aligned}
& y_{i t}=\alpha_{1} y_{i t-1}+\beta_{1} x_{i t-1}+\eta_{i}+\phi_{t}+v_{i t}, \\
& i=1,2, \ldots N ; t=1,2, \ldots T
\end{aligned}
$$

where in our case $y_{i t}$ is either private or public investment (deflated and in per capita terms) and $x_{i t}$ will real per capita GDP. The reverse relationship is also explored for the whole sample and OECD sub-sample.

The model in (3) allows for unobserved heterogeneity through the individual effect $\eta_{i}$ that captures the joint effect of time-invariant omitted variables. $\phi_{t}$ is a common time effect, while $v_{i t}$ is the disturbance term. We also assume that $x_{i t}$ is potentially correlated with $\eta_{i}$ and may be correlated with $v_{i t}$, but is uncorrelated with future shocks $v_{i t+1}, v_{i t+2}, \ldots$ Under these assumptions, $x_{t-1}$ is predetermined with respect to $v_{i t}$ and the errors can be assumed to satisfy sequential moment conditions of the form: $E\left(v_{i t} \mid y_{i}^{t-1}, x_{i}^{t-1}, \eta_{i}, \phi_{t}\right)=0$, where $y_{i}^{t-1}=\left(y_{i 1}, y_{i 2}, \ldots, y_{i t-1}\right)^{\prime}$ and $x_{i}^{t-1}=\left(x_{i 1}, x_{i 2}, \ldots, x_{i t-1}\right)^{\prime}$. When these moment conditions are satisfied, the errors are conditionally serially uncorrelated and this implies that $E\left(v_{i t}, v_{i t-j}\right)=0$. The model can be estimated by first-differencing (3) to get rid of the individual effects, and then using lagged levels of $y_{i t}$ and $x_{i t}$ dated $t-2$ (and earlier) as instruments. However, a more efficient GMM estimator can be employed by using more of the available moment conditions, as suggested by Arellano and Bond (1991), who proposed the use of all available lagged levels of $y_{i t}$ and $x_{i t}$ dated $t-2$ (and earlier). We name this estimator DIF-GMM. In this context, we also use Hansen J's test to assess the model specification and overidentifying restrictions.

As there are a number of limitations of DIF-GMM estimation ${ }^{17}$, under the assumptions set in Arellano and Bover (1995), the system-GMM estimator can be used to alleviate the weak instruments problem. In our setting, the SYS-GMM uses the standard moment conditions, while SYS-GMM1 (modified 1) only uses the lagged first-differences of $y_{i t}$ dated t-2 (and earlier) as instruments in levels and SYS-GMM2 (modified 2) only uses lagged firstdifferences of $x_{i t}$ dated t-2 (and earlier) as instruments in levels.

In the AR(1) model, one hypothesis of economic interest is the null $\beta_{1}=0-$ this can be interpreted as a panel data test for Granger causality. Even though a Wald-type test of this restriction (a standard t-ratio) could be used, we make use of an alternative methodology.

\footnotetext{
${ }^{17}$ For instance, the lagged levels of the series may be weak instruments for first differences, especially when they are highly persistent, or the variance of the individual effects is high relative to the variance of the transient shocks
} 
Specifically, we estimate both the unrestricted and the restricted models using the same moment conditions, and then compare their (two-step) Hansen $\mathrm{J}$ statistics using an incremental Hansen test defined as:

$$
D_{R U}=n(J(\widetilde{\gamma})-J(\hat{\gamma}))
$$

where $J(\widetilde{\gamma})$ is the minimized GMM criterion for the restricted model, $J(\widehat{\gamma})$ for the unrestricted model, and $n$ is the number of observations. Under the null, $D_{R U}$ is asymptotically distributed as $\chi_{r}{ }^{2}$ where $r$ is the number of restrictions. The intuition is that, if the parameter restriction $\left(\beta_{1}=0\right)$ is valid, the moment conditions should keep their validity even in the restricted model. $^{18}$

There are some additional issues of interpretation worth discussing in the context of the use of the above model. One may be interested in the stability of the estimated model. If our model is stable, we can compute a point estimate for the long-run effect of $x_{i t}$ on $y_{i t}$ :

$$
\beta_{L R}=\beta_{1} /\left(1-\alpha_{1}\right),
$$

and we can estimate an approximate standard error for this long-run effect using the Delta Method.

\section{Cross-sectional dependence}

We are aware of the potential issue (in particular, bias in coefficient estimates) induced by a significant cross-sectional dependence (within similar groups of countries in our sample) in the error term of the model. As put forward by Eberhardt et al. (2010), the so-called unobserved common factor technique relies on both latent factors in the error term and regressors to take into account the existence of cross-sectional dependence. Developed with the panel-date/time-series econometric literature over the course of the past few years, this method has been largely employed in macroeconomic panel data exercises (see, e.g., Pesaran (2004, 2006), Coakley et al. (2006), Pesaran and Tosetti (2007), Bai (2009), Kapetanios et al. (2009) and Eberhardt and Teal (2011 and references therein)). This common factor methodology takes cross-sectional dependence as the outcome of unobserved time-varying omitted common variables or shocks which influence each cross-sectional element in a different way. Cross-sectional dependence in the error term of the estimated model results

\footnotetext{
${ }^{18}$ For more details see Bond and Windmeijer (2005).
} 
then in inconsistent coefficient estimates if independent variables are correlated with the unspecified common variables or shocks. ${ }^{19}$

With this in mind, we test for the presence of cross-sectional dependence Pesaran's (2004) CD test statistic based on a standard normal distribution. We then run some of the most important regression equations with Driscoll-Kraay (1998) robust standard errors. This nonparametric technique assumes the error structure to be heteroskedastic, autocorrelated up to some lag and possibly correlated between the groups. Given the particular nature of the dependent variable and the possibility of error dependence another estimation approach would be worthwhile. We rely on the Pesaran (2006) common correlated effects pooled (CCEP) estimator, a generalization of the fixed effects estimator that allows for the possibility of cross section correlation. Including the (weighted) cross sectional averages of the dependent variable and individual specific regressors is suggested by Pesaran (2006, 2007, and 2009) as an effective way to filter out the impacts of common factors, which could be common technological shocks or macroeconomic shocks, causing between group error dependence.

\section{Empirical analysis}

The dataset was collected from several sources for 95 countries for the period 1970$2008 .{ }^{20}$ Our main dependent variables are: 1) private investment and 2) public investment (both as shares of GDP).

Fiscal variables come from the WDI, the IMF's International Financial Statistics (IFS) and Easterly's (2001) data. They comprise the budget balance (\% GDP) and the Central Government Debt (\% GDP) - the latter retrieved from the IMF's historical debt database due to Abas et al. (2010). On the government revenue side we have, as \% of GDP: Total Government Revenue, Tax Revenue, Taxes on Goods and Services, Taxes on Payroll or work force, Taxes on Income, Profits and Capital Gains, Taxes on Property, and Social Contributions. On the government expenditure side we consider, as a \% of GDP: Total Government Expenditure, Compensation of Employees, Interest Payments, Subsidies, Public Final Consumption Expenditure, and a functional decomposition comprising of Spending on Education, Spending on Health, and Spending on Social Security and Welfare.

With respect to human capital proxies we mainly rely on the average years of schooling in the population over 25 years old from the international data on educational attainment by

\footnotetext{
${ }^{19}$ There are different ways to account for such error cross-sectional dependences (see, e.g., Sarafidis and Wansbeek (2010) for an overview).

${ }^{20}$ A summary with definitions, acronyms and sources is presented in the Appendix.
} 
Barro and Lee (2010), but we also take, for robustness, the literacy rate ( $\%$ of people aged 15 to 24 ), primary school enrolment ( $\%$ of gross), primary school duration (years), secondary school enrolment ( $\%$ gross), secondary school duration (years), tertiary school enrolment (\% gross) and tertiary school duration (years) from the WDI, for robustness purposes.

As for other controls and regressors, most come from either the WDI or from the IMF's IFS, as follows: land area (in square kilometres), population, imports and exports of goods and services (BoP, current USD), labour participation rate ( $\%$ of total labour force), labour force, unemployment, ( $\%$ of total labour force), fertility rate (births per woman), age dependency ratio ( $\%$ of working age population), urban population ( $\%$ of total), terms of trade adjustment (constant LCU), real effective exchange rate index $(2000=100)$.

\subsection{Model selection}

One reason for the strong appeal of the BMA is that the weights in the final averaging procedure are tied quite closely to the predictive ability of the different models. Vis-à-vis the Extreme Bounds Analysis, in the BMA there is no set of fixed variables included and the number of explanatory variables in the specifications is flexible. In Table 1a we have the results from our BMA application where the dependent variable is the level of private investment (GFCF) over GDP. The BMA yields posterior probabilities of inclusion (PIP) and a sign certainty index of a relationship. ${ }^{21} \mathrm{We}$ present 10 different possible models containing different sets of regressors grouped by type: scale/size, living conditions, policy/institutional, education and, finally, government.

[Table 1a]

A first result is that the initial level of per capita GDP should be included and it has in several cases the expected negative (and significant) sign, translating the conditional beta-type convergence hypothesis. Moreover, size, proxied notably by land area is detrimental to private investment. Other interesting results are the fact that fertility rates, age dependency ratio and unemployment (proxying living conditions and state of development) have a negative effect on private investment. Policy variables such as openness to international trade have a positive impact on private investment, and the same is true with institutional measures such as the Freedom House index and the Corruption Perception Index. Furthermore, there is a positive impact of human capital. With respect to government-related variables the main findings are: i) (some) taxes seem to have a positive effect on private investment, ii) a positive

\footnotetext{
${ }^{21}$ A sign is given to the PIPs greater than 0.5 ; no sign means the sign of the estimated relationship is uncertain.
} 
effect attributed to both total government expenditures as well as public investment in fostering private investment, iii) a negative effect of both government expenditure on wages and government consumption spending on private investment.

[Table 1b]

With respect to public investment (see Table 1b), results are less clear-cut but we find unemployment affecting it adversely and so does education. Revenues present mixed evidence (naturally depending on whether taxes will be spent on productive or unproductive activities). Higher government expenditure on health is associated with larger public investment.

Finally, in Table 2 for both dependent variables previously discussed we report the top models based on their R-squares. All in all, the best models include expenditure components and signal the relatively less important impact attributed to government revenues' categories.

[Table 2]

\subsection{Budgetary economic (de-)composition}

Table 3 presents the results for our two benchmark equations (1) and (2) using fixedeffects and system-GMM approaches. ${ }^{22}$ Population growth has a positive impact on both types on investment, whereas, in general, initial GDP per capita hampers investment (similarly as in the case of the catching-up hypothesis within the empirical growth literature). Evidence seems to suggest that age structure of a country also affects investment. For private investment a higher dependency ratio has a negative impact, whereas for public investment the effect is reversed. In the former case, if a high proportion of the population is of working age then the economy should have a high rate of private saving and investment would flourish (Modigliani's life-cycle hypothesis). Higher proportions of the young and elderly in relation to persons of working age are associated with lower saving rates and investment (Siddiqui and Siddiqui, 1993; Khan et al., 1992). Yet another explanation for the negative sign comes from the fact that this may reflect the tendency for scarce or costly prime-age labour to depress the returns on private investment and make it less attractive. Decreasing labour supply reduces the demand for investment goods insofar as there is less labour for capital to cooperate with.

Additionally, some forms of investment may be rendered less attractive by the diminishing returns to scale associated with a smaller or more slowly growing population. In the latter case - the positive sign in the case of public investment - a higher dependency-ratio

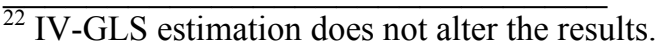


exerts a positive influence on the government spending share in general, primarily through human capital widening demands (by requiring larger budget and public investment to educate the large number of school age children) and by increasing the expenditures for the social security and medical care (and associated public investment in hospitals and related healthcare facilities, Kelley, 1976). ${ }^{23}$

\section{[Table 3]}

Given our benchmark equations (1)-(2) together with their respective set of controls, we now move to the inclusion of different sub-components of government revenues and expenditures. In Table 4 we include each item, one at a time, in a regression of interest, for private and public investment.

\section{[Table 4]}

Inspecting first the revenues' panel we observe that each component does not significantly affect private or public investment in OECD countries. However, taxes on income, profits and capital gains as well as social security contributions have a statistically significant positive impact on public investment for the full sample and emerging economies sub-group, but not for the OECD. This may seem counterintuitive, but Helms (1985) and Mofidi and Stone (1990) found that taxes spent on publicly provided productive inputs tend to (ultimately) enhance growth via appropriate investment spending. ${ }^{24}$

Turning to the expenditures' panel, interest payments and subsidies have a negative effect on both types of investment (particularly in the emerging economies sub-group), the latter eventually due to the fact that it creates deadweight loss inefficiencies when distorting the market from its own natural equilibrium. On the other hand, higher public interest payments imply an additional burden on the public purse, making it more difficult to finance public investment. For private investment, financing conditions may also become stricter due to possible spillover effects, from higher sovereign yields into, the funding of private investment.

A natural step to take further is to include all components of each budgetary block simultaneously in equations (1)-(2). Table 5a reports the results for the revenue block. Domestic taxes on goods and services appear now with a statistically significant negative coefficient in the private investment regression (specification 3). For taxes on income, profits and capital gains, the positive significance is kept. As regards the OECD sub-group, revenue

\footnotetext{
${ }^{23}$ For robustness Appendix B presents the results from Bruno's (2005) LSDV-C estimator. Results are consistent with previous findings.

${ }^{24}$ Theoretically, in Barro-style models, increases in taxes can enhance, have no effect or impede growth depending, in particular, on the initial level of taxes as well as how revenues are spent.
} 
variables are never significant in private investment equations. In general, revenues keep their positive signs and statistical significance when explaining the level of public investment (a relationship coming from the possibility of an increased inflow of available funds to spend). Taking account of endogeneity problems (with a corresponding panel IV-GLS approach - not shown) increases the significance level in most coefficients, in particular the basic set of controls (positive effect of population growth in $I 1$ and $I 2$ ), the overall negative effect of taxes on private investment, but their positive effect on public investment. Most revenues' coefficients for the OECD sub-group remain insignificant. Alternatively, running systemGMM for the full sample (specifications 7-8) removes any statistically significance out of the revenue's categories, confirming Easterly and Rebelo's (1993) claim that taxes are difficulty to isolate empirically.

[Table 5a]

Regarding the expenditure items in Table 5b, on average, the R-squares are somewhat higher than when disaggregated revenues are included in the regressions (particularly for the OECD sub-group). Overall, evidence suggests a higher importance attributed to government expenditures than to revenues. Apart from expected signs on the basic set of controls as already discussed, a closer inspection indicates that interest payments is detrimental in both investment equations (when running both FE and SYS-GMM). On the other hand, subsidies appear with positive and statistically significant coefficients in private investment (OECD) and in public investment (emerging economies) equations. As with the case of government revenues, when endogeneity is taken into account, most coefficients increase their significance levels with "right" sign estimates. Moreover, R-squares increase from FE to IVGLS estimation in every specification.

\section{[Table 5b]}

\subsection{Decomposition of functional spending}

Government spending can play an essential role in the economic development of a country by maintaining law and order, providing economic infrastructure, harmonizing conflicts between private and social interests, increasing labour productivity through education and health and enhancing export industries. Hence, in terms of the functional decomposition of government expenditures, we differentiate the effects from spending on education, health, and social security (and welfare), which constitute the main items of government spending. 
In Table 6, Panel A, each of the abovementioned spending categories is included in the regression for private investment one at a time. For reasons of parsimony we do not report the full set of coefficient estimates. Regarding social security spending, it has a statistically negative effect on private investment for the full and OECD samples. ${ }^{25}$ Concerning government health spending it appears with a positive and significant coefficient for private investment, which is positively correlated with population growth and by itself has a positive impact on investment levels. In Panel $\mathrm{B}$, the three variables of interest are included simultaneously in each regression and, in general, the same conclusions apply.

[Table 6]

\subsection{Non-linearities in budgetary decomposition}

The presence of large government debt burdens constitutes a source of uncertainty in the macroeconomic environment. Government debt may affect private investment in several ways. First, the size and timing of external transfers to the country's creditors may be uncertain as it depends on future levels of the world interest rates, terms of trade, the purchasing power of exports and the ability to reschedule debt. Thus, the level of the real exchange rate and the timing of demand management policies consistent with the required transfer also become uncertain (Borenzstein, 1989). Second, funds available for investment will be reduced where a higher debt service payment is involved. Third, many developing countries face liquidity constraints in international capital markets because of large arrears on debt service obligations (Krugman, 1988; Corden, 1988). Finally, several studies have emphasized that a heavy debt overhang reduces the incentive to invest because the anticipated foreign tax on future income and returns on investment (Serven and Solimano, 1991; Greene and Villanueva, 1991). A high debt-to-GDP ratio means that part of future returns on any investment must be used to service the existing stock of debt. Empirical results have confirmed that high debt-to-GDP ratio has a strong negative impact on the private investment rates in developing countries (Pindyck and Rubinfeld, 1991).

Hence, an additional exercise is to further explore possible effects coming from nonlinearities in the context of the budgetary decomposition we have been discussing. One may be inclined to think that the reduction of budget deficits (or government debt) can be conducive to higher growth via increased investment (at least private one, through a reduced probability of - implicit - crowding-out effects). Of interest is whether our results hold for all

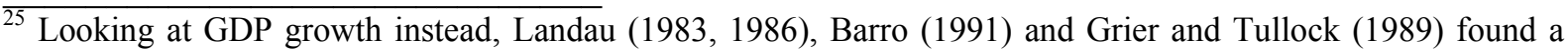
negative relationship between social expenditures and growth.
} 
countries in the sample, in particular, for countries that have already achieved a modicum of macroeconomic (fiscal) stability. ${ }^{26}$ Therefore, we split the sample into countries so-called "above" or "below", based on a given fiscal threshold. Specifically, an "above" type country is defined as a country that maintained on average (over time) a budget deficit below $3 \%$ of GDP; conversely, a "below" type country is such that it maintained an average budget deficit above $3 \%$ of GDP. ${ }^{27}$ We also repeat the procedure with a $60 \%$ of GDP government debt threshold (that is, the "above" type country is one that maintained an average debt ratio below $60 \%$ of GDP over the period; mutatis mutandis for the "below" case). ${ }^{28}$ Figure 2 summarizes such split. One does not see much difference when looking at private investment, but the same does not apply to public investment which is always somewhat lower in countries with higher (deficit or debt). This may indicate when facing relevant fiscal imbalances the government more quickly reduces capital spending.

Figure 2: Bar-chart of private and public investment performance as a function of the full sample's budgetary and debt averages

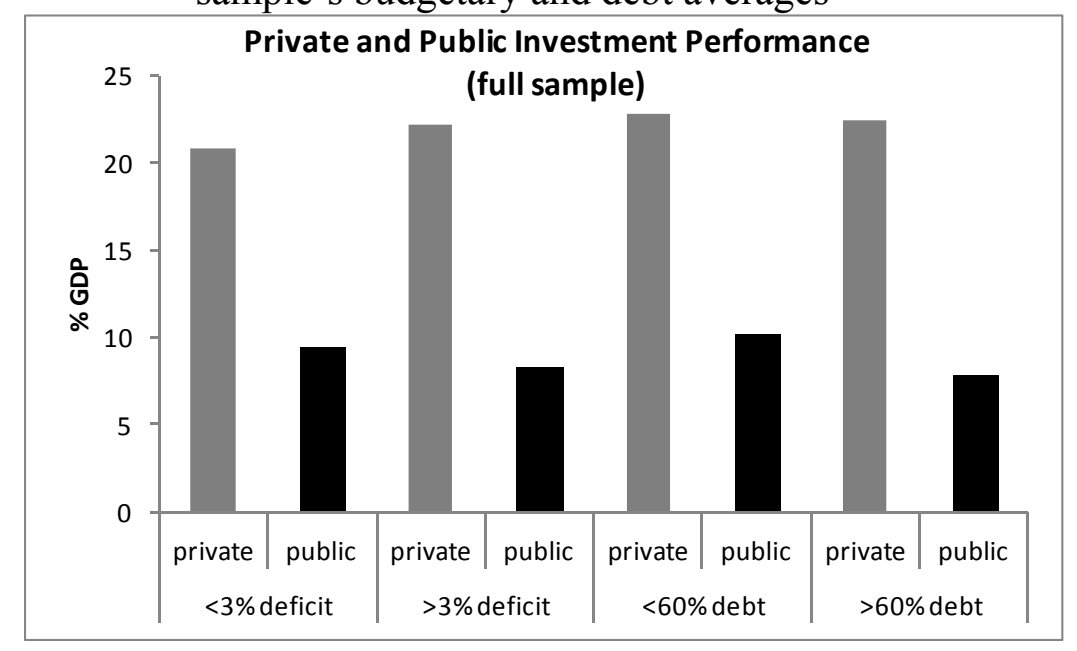

Note: " $<3 \%$ deficit" denotes the cross-sectional average of private and public investment as percentage of GDP for the set of countries which maintained a budget deficit-to-GDP ratio below $3 \%$ over the full time span considered - "above" type countries. Mutatis mutandis for " $>3 \%$ deficit". " $<60 \%$ debt" denotes the crosssectional average of private and public investment as percentage of GDP for the set of countries which

\footnotetext{
${ }^{26}$ On the same line, see Adam and Bevan (2001) and Gupta et al. (2005).

${ }^{27}$ The 3\% value is an ad-hoc number stemming from the European Union Stability and Growth Pact (SGP) rationale. For the OECD sub-group, countries classified as being "above" average, lower budget deficits, are: Australia, Canada, Czech Republic, Denmark, Finland, France, Germany, Iceland, Korea, Luxembourg, Netherlands, New Zealand, Norway, Poland, Slovakiam Spain, Switzerland, UK and US. The "below" average ones, higher deficits, are: Austria, Greece, Hungary, Ireland, Italy, Japan, Mexico, Portugal, Sweden and Turkey. ${ }^{28}$ The $60 \%$ limit for the debt ratio is related to the SGP framework, although also endogenously computed in Afonso and Jalles (2011b), above which government debt is detrimental to growth - see further details therein. According to this threshold for the OECD sub-group, countries classified as "above" average, lower debt ratio, are: Australia, Czech Republic, Denmark, Finland, Germany, Iceland, Ireland, Japan, Korea, Luxembourg, Mexico, Netherlands, New Zealand, Norway, Slovakia, Spain, Sweden, Switzerland, Turkey, UK and US. The "below" average ones, higher debt ratio, are: Austria, Belgium, Canada, France, Greece, Hungary, Italy and Portugal.
} 
maintained a total government debt-to-GDP ratio below $60 \%$ over the full time span considered - "above" type countries. Mutatis mutandis for " $>60 \%$ debt". Source: Authors' estimates.

Below we report the results with the $3 \%$ deficit threshold. We do not include debt explicitly in our econometric specification (as in Chirinko and Schaller, 1995) since its impact on investment decisions, though important, may be a priori unpredictable. Needless to say that some of these results require care in interpretation given the truncated nature of the resulting sample and reduced number of available observations. Using as the dependent variable private investment yields, generally, insignificant coefficients for both revenues' and expenditures' components, so we refrain from presenting and commenting on this set of results. Focusing on the public investment regression instead, we get from Table 7 that countries which maintained an average public deficit above 3\% of GDP are negatively affected by interest payments, subsidies and government consumption expenditure (statistically significant at 5 and 1\% levels). This compares with insignificant expenditure components' coefficient estimates for the case of below the 3\% of GDP average deficit level.

[Table 7]

As described above, for robustness, we also used a $60 \%$ threshold for the average public debt-to-GDP ratio over a country's time series span. For reasons of parsimony results are available upon request. Overall, we get mixed evidence from revenues' components coefficient estimates. As for the expenditures' components, interest payments and government final consumption appear with statistically significant negative signs for debt above $60 \%$ of GDP. Redoing these estimations with the truncated set of basic regressors or using the 5-year average period debt-rule instead of the country average, doesn't alter the main results (not shown).

\subsection{Panel Granger-causality tests}

It also seems important to understand whether expenditures (revenues) Granger cause per capita private investment or even if GDP per capita Granger causes either private or public investment (or the reverse applies or even if one finds two-way causality). First, we don't find evidence of causality running from either real total government expenditures per capita or real total government revenues per capita to real private investment per capita. ${ }^{29}$ If we test the GDP-investment relationship, in Table $8 \mathrm{a}$ we get some evidence of causality from real GDP per capita to real Private Investment per capita.

\footnotetext{
${ }^{29}$ Both private and public investment(\% of GDP) as well as total government expenditures and revenues were converted to nominal levels, deflated using the CPI and scaled by population.
} 
[Table 8a]

Out of 6 econometric specifications, 2 support Granger causality, with both models (1) and (2) indicating a positive short and long-run effect of GDP on private investment. The reverse relationship also holds and it is actually slightly stronger, with models (4)-(6) in Table $8 \mathrm{~b}$ pointing to causality running from private investment to GDP. Since results using public investment instead are uninteresting (with short and long-run insignificant coefficient estimates and non-rejection of the null of non-Granger causality) we refrain from presenting and commenting on this set of results.

If we try to uncover causality running from public to private investment, we obtain statistically insignificant results irrespectively of the econometric specification.

\subsection{Cross-sectional dependence}

As discussed in Section 3 it is natural to suspect about the existence of cross-sectional dependence across homogeneous groups of economies. Therefore, we use Pesaran's CD test ${ }^{30}$ for the OECD sub-samples and we find a statistic of 12.05, corresponding to a p-value of zero (the null hypothesis is cross-sectional independence). In Table 9 we run benchmark type investment regressions for this OECD sample using both a Driscoll Kraay robust estimation approach and the Pesaran's Common Correlated Effects Pooled Estimator (CCEP). We restrict ourselves to the examination of four main variables of interest: total government expenditures and revenues (\% of GDP) and their respective growth rates.

[Table 9]

Evidence in Table 9 suggests that government revenues have a detrimental effect on private investment; the reverse is true for public investment. However, revenues' and expenditures' growth rates have a positive effect on private investment and none on public investment.

\subsection{Numerical Fiscal Rules}

In the context of the EU, Member States face a fiscal framework based on the implementation of sound fiscal policies, notably within the Stability and Growth Pact (SGP) guidelines put forward in 1997. In fact, self-enforced institutional restrictions to budgetary decision-making are a common feature of fiscal governance in advanced countries (see Hallerberg et al., 2007 for an overview). In addition to excess spending in the absence of such

\footnotetext{
${ }^{30}$ A standard investment equation including a basic set of controls and the debt ratio is estimated with within fixed effects.
} 
rules, previous literature also suggests that the so-called "common pool problem" may induce a pro-cyclical bias in fiscal policy (Tornell and Lane, 1999). Yet another rational for the implementation of such numerical rules is to prevent policymakers from exacerbating macroeconomic volatility which is known to be detrimental to output growth. However, the Member States' track records of complying with the fiscal rules laid down in the SGP have been mixed. ${ }^{31}$ Therefore, it is relevant to assess whether such numerical fiscal rules, while aiming at improving fiscal positions, also play a role in fostering (public) investment. To our best knowledge such an empirical exercise has never been conducted.

Therefore, we use the three indices constructed by the European Commission (overall rule index, expenditure rule index, and budget balance and debt rule index). ${ }^{32}$ Table 10 reports our findings between 1990-2008 using fixed-effects.

[Table 10]

Based on equation (2), we find on specifications (1)-(3) statistically significant negative coefficients on the overall rule index and the budget balance rule index, meaning that having strong fiscal numerical rules, notably by promoting sounder fiscal behaviour, also decreases the amount of capital available for public investment for these set of EU countries.

Finally, we also tested specifications in which our sample is split based on the countryaverage debt-to-GDP ratio over the entire time period being higher or lower than $60 \%$ (in line with the SGP threshold level). Specifications (4)-(6) redo the exercise for countries with debt level below $60 \%$ over the period and we get insignificant coefficient estimates for all three fiscal rules (despite keeping their negative sign). In contrast, countries that maintained an average public debt over $60 \%$ get a slightly stronger (in magnitude) overall rule index (and identical magnitude and statistical significance for the budget balance rule index).

\section{Conclusion}

We have used cross-sectional/time series data for a panel of 95 developed and developing countries for the period 1970-2008, in order to assess the potential linkage between fiscal policy developments and investment. More specifically, we focused on a number of econometric issues that could have an important bearing on the results, notably simultaneity,

\footnotetext{
${ }^{31}$ The European Commission (2006) points to significant heterogeneity of national fiscal frameworks within the EU and suggests that "stronger" fiscal rules are conducive to sound public finances (and ultimately more efficient and growth-enhancing economic policies).

${ }^{32}$ These indices are normalized to have a zero mean and unit variance. They are based on a survey conducted by the Working Group on the Quality of Public Finances among practitioners and researchers in the field of fiscal policy. These measures bear strong appeal for empirical implementations as they translate a broad set of institutional provisions into a country-specific cardinal ranking (see Deburn at al., 2008, and Afonso and Hauptmeier, 2009 for details).
} 
endogeneity, (two-way) causality, the relevance of nonlinearities and threshold effects, crosssection dependence and numerical fiscal rules. Our results coming out of the Model Selectionbased techniques suggest a positive effect attributed to both total government expenditures as well as public investment in fostering private investment and negative effects of both government expenditure on wages and government consumption spending on private investment. With respect to public investment, revenues present mixed evidence (naturally depending on whether taxes will be spent on productive or unproductive activities), but higher government expenditure on health is associated with larger public investment.

Our evidence also suggests that population growth has a positive impact on both types on investment, whereas, in general, initial GDP per capita hampers investment. More importantly, evidence seems to suggest that age structure of a country also affects investment: for private investment a higher dependency ratio has a negative impact, whereas for public investment the effect is reversed. If we decompose revenues, we observe that each component (when introduced individually) does not significantly affect private or public investment in OECD countries. However, taxes on income, profits and capital gains as well as social security contributions have a statistically significant positive impact on public investment for the full sample and emerging economies sub-group, but not for the OECD. As for expenditures, interest payments and subsidies have a negative effect on both types of investment (particularly in the emerging economies sub-group). Regarding the functional classification of government spending, social security spending has a statistically negative effect on private investment for the full and OECD samples, whereas government health spending it appears with a positive and significant coefficient for private investment. Moreover, exploring non-linearities we see that public investment is always lower in countries with higher deficit/debt. Furthermore, countries which maintained average government budget deficits above $3 \%$ of GDP are, more strongly, negatively affected by interest payments, subsidies and government consumption expenditure. Results are robust to several econometric procedures.

Cross-sectional dependence regressions suggest that government revenues have a detrimental effect on private investment; the reverse is true for public investment. However, revenues' and expenditures' growth rates have a positive effect on private investment and none on public investment.

Granger causality tests find evidence supporting causality running from GDP to private investment and the reverse appears to be stronger (with both positive short and long-run effects). 
We also find statistically significant negative coefficients on the overall EU fiscal rule index and the budget balance rule index, meaning that having good fiscal numerical rules may decreases notably fiscal imbalances but also the amount of capital available for public investment for the EU countries. One can wonder whether the fiscal imbalance is then not first tackled by the governments via cuts in capital spending, which would in principle be more growth enhancing than current spending.

All in all, evidence suggests a higher importance attributed to government expenditures than to revenues in explaining either private or public investment levels.

\section{References}

1. Abas, A., Belhocine, N., ElGanainy, A., Horton, M. (2010), “A Historical Public Debt Database", IMF Working Paper No. 10/245.

2. Adam, C.S., Bevan, D.L., (2001), "Nonlinear effects of public deficits on growth", Paper prepared at the Cornell/ISPE Conference, New York, September.

3. Afonso, A. and Furceri, D. (2010), "Government size, composition, volatility and economic growth", European Journal of Political Economy, 26 (4), 517-532.

4. Afonso, A. and Hauptmeier, S. (2009). "Fiscal behaviour in the EU: rules, fiscal decentralization and government indebtedness", ECB WP 1054.

5. Afonso, A. and Jalles, J. T. (2011a), "Economic Performance and Government Size: a political economy assessment", mimeo

6. Afonso, A. and Jalles, J. T. (2011b), "Growth and Productivity: the role of Government Debt”, ISEG-UTL, Department of Economics, Working Paper nº 13/2011/DE/UECE.

7. Afonso, A. and St. Aubyn, M. (2009). "Macroeconomic Rates of Return of Public and Private Investment: Crowding-in and Crowding-out Effects", Manchester School, 77 (S1), 21-39.

8. Arellano, M. (2003), "Panel data econometrics", Oxford University Press, Oxford.

9. Arellano, M. and Bover, O. (1995), "Another Look at the Instrumental Variable Estimation of Error Component Models", Journal of Econometrics, 68: 29-51.

10. Arellano, M. and S.R. Bond (1991), "Some tests of specification for panel data: Monte Carlo evidence and an application to employment equations", Review of Economic Studies, 58, 277-297.

11. Bai, J. (2009), "Panel data models with interactive fixed effects", Econometrica, 77(4), 1229-1279.

12. Balassa, Bella (1988), "Public Finance and Economic Development", World Bank Working Paper, 31.

13. Barro, R. and Lee, J.W. (2010), "International data on educational attainment, updates and implications", WP 42, Center for International Development, Harvard University.

14. Barro, R. J. (1991), "Economic growth in a cross section of countries", Quarterly Journal of Economics, 106, 407-44.

15. Barro, R.J. and J.W. Lee (1993), "Losers and Winners in Economic Growth", Proceedings of the World Bank Annual Conference on Development Economics, ed. M. Bruno and B. Pleskovic, 267-97.

16. Beddies, C. (1999), "Investment, Capital Accumulation and Growth: Some Evidence from Gambia: 1964-1998", IMF Working Paper 99/117. 
17. Ben-David, D. (1998), "Convergence Clubs and Subsistence Economies", Journal of Development Economics, 55, 155-171.

18. Bischoff, C. W. (1971), "Business investment in the 1970s: a comparison of models", Brookings Papers on Economic Activity, 13-58.

19. Bljer, M and M. Khan (1984), "Government Policy and Private Investment in Developing Countries", IMF Staff Paper, 131, International Monetary Fund, Washington, D. C.

20. Blomstrom, M., Lipsey, R. and Zejan, M. (1996), "Is fixed investment the key to economic growth?", Quarterly Journal of Economics 111: 269-276.

21. Bloom, Nicholas, Stephen Bond, and John Van Reenen (2001), "The dynamics of investment under uncertainty", Institute for Fiscal Studies (IFS), Working Paper No. $01 / 05$.

22. Bond. S.R. and F. Windmeijer (2005), "Reliable inference for GMM estimates? Finite sample properties of alternative test procedures in linear panel data models", Econometric Reviews, 24(1), 1-37.

23. Borensztein, E. (1990). "Debt Overhang, Debt Reduction and Investment: The Case of the Philippines", IMF Working Paper 77, International Monetary Fund.

24. Borenzstein, E. (1989), "Debt overhang, credit rationing and investments", Journal of Development Economics, 32, 315-35.

25. Bruno, G. (2005), "Approximating the bias of the LSDV estimator for dynamic unbalanced panel data models", Economics Letters, 87(3), 361-366.

26. Butzen, Paul, Catherine Fuss and Phillip Vermeulen (2002), "The impact of uncertainty on investment plans", National Bank of Belgium, Working Paper No. 24.

27. Campos, Nauro, and Jeffrey Nugent (2003), "Aggregate investment and political instability: An econometric investigation", Economica 70, 533-49.

28. Cardoso, E. (1993), "A Private Investment in Latin America”, Economic Development and Cultural Change, 41, 833-848.

29. Chari, V.V., P.J. Kehoe and E. R. McGrattan (1997), "The Poverty of Nations: A Quantitative Investigation”, Research Department Staff Report 204, Federal Reserve Bank of Minneapolis, Minneapolis.

30. Chirinko, R. and Schaller, H. (1995), "Why does liquidity matters in investment equations?", Journal of Money, Credit and Banking 27, 527-548.

31. Clark, P. K. (1979), "Investment in the 1970s: theory, performance and prediction", Brookings Papers on Economic Activity, 73-113.

32. Coakley, J., Fuertes, A.-M. and Smith, R. (2006), "Unobserved heterogeneity in panel time series models", Computational Statistics \& Data Analysis, 50(9), 2361-2380

33. Collier, P. and J.W. Gunning (1999), "Explaining African Economic Performance", Journal of Economic Literature, 37, 64- 111

34. Corden, W. M. (1988), "Debt relief and adjustment incentives", IMF Staff Papers, 25, 628-43.

35. De Gregorio, J. (1991), "Economic growth in Latin America", IMF Working Papers $91 / 71$.

36. De Haan, J., Sturm, J.E., and Sikken, B.J. (1996), "Government capital formation: Explaining the decline," Weltwirtschaftliches Archiv, 132, 55-74.

37. Debrun, X., Moulin, L., Turrini, A., Ayuso-i-Casals, J. And Kumar, M. (2008), "Tied to the mast? National Fiscal rules in the EU", Economic Policy, 23(54), 297-362.

38. Devarajan, S. V., V. Swaroop and H. Zou. (1996), "The Composition of Public Expenditure and Economic Growth", Journal of Monetary Economics, 37, 313-344 
39. Driscoll, John and Aart C. Kraay, (1998), "Consistent Covariance Matrix Estimation With Spatially Dependent Panel Data", Review of Economics and Statistics, 80(4), 549560

40. Easterly, W. and Rebelo, S. (1993), "Fiscal policy and economic growth", Journal of Monetary Economics, 32, 417-458.

41. Eberhardt, M., Helmers, C. And Strauss, H. (2010), "Do spillovers matter when estimating private returns to R\&D?", Economic and Financial Reports 2010/1, EIB.

42. Eberhardt, M. and Teal, F. (2011), "Econometrics for Grunblers: A new look at the literature on cross-country growth empirics", Journal of Economic Surveys, 25(1), 109155.

43. European Commission (2003), "Public Finances in EMU", Luxembourg, DG for Economic and Financial Affairs.

44. European Commission (2006), "Public Finances in EMU", European Economy, 3.

45. Everhart, S. and Sumlinski, M. (2001), "Trends in private investment in developing countries: statistics for 1970-2000", World Bank, Washington D.C.

46. Gali, J. and Perotti, R. (2003), "Fiscal policy and monetary integration in Europe", Economic Policy, 18, 533-72.

47. Ghura, D. (1997), "Private Investment and Endogenous Growth: Evidence from Cameroon", IMF WP 97/165.

48. Ghura, D. and T. Hadjimichael (1996), "Growth in Sub-Saharan Africa", IMF Staff Papers, International Monetary Fund, 43.

49. Green, J. and Villanueva, D. (1991), "Private investment in developing countries: an empirical analysis", IMF Staff Papers, 38, 33-58.

50. Grier, K. B. and G. Tullock, (1989) "An Empirical Analysis of Cross-National Economic Growth: 1951-80", Journal of Monetary Economics, 24(2), 259-76.

51. Gupta, S., Baldacci, E., Clements, B., Tiongson, E.R. (2005), "What sustains fiscal consolidations in emerging market countries?", International Journal of Finance and Economics, 10, 307-321.

52. Hallerberg, M., Strauch, R. and von Hagen, J. (2007), "The design of fiscal rules and forms of governance in EU countries", European Journal of Political Economy, 23, 338-359.

53. Herandez-Cata, E. (2000), "Raising Growth and Investment in Sub-Saharan Africa: What Can be Done?", Policy Discussion Paper: PDP/00/4, International Monetary Fund, Washington, D .C.

54. Huang, Y. and Temple, J. (2005), "Does external trade promote financial development?" Bristol Economics Discussion Papers 05/575.

55. Sturm, J.-E. and De Haan, J. (2000), "On the relationship between economic freedom and economic growth", European Journal of Political Economy 16, 215-241.

56. Jorgenson, D. W. (1967), "The Theory of Investment Behaviour", in Determinants of Investment Behaviour, ed. R. Ferber, NBER.

57. Jorgenson, D. W. (1971), "Econometric Study of Investment Behaviour: a survey", Journal of Economic Literature, 9, 1111-47.

58. Kapetanios, G., Pesaran, M. H., Takashi, Y. (2009), "Panels with nno-stationary multifactor error structures", unpublished working paper, updated version of IZA WP No. 2243.

59. Kelley, A. C., "Demographic Change and the Size of the Government Sector," Southern Economic Journal, 1056-1066.

60. Khan, A. H., L. Hassan, and A. Malik (1992), "Dependency Ratio, Foreign Capital Inflows and the Rate of Savings in Pakistan", The Pakistan Development Review 31(4), 843-856. 
61. Khan, M.S., and C.M. Reinhart (1990), "Private Investment and Economic Growth in Developing Countries", World Development, 18 (1), 19-27.

62. Khan, M.S., and M.S. Kumar (1993), "Public and Private Investment and the Convergence of Per Capita Incomes in Developing Countries," IMF Working Paper, $\mathrm{WP} / 93 / 51$.

63. Kormendi, R.C. and P.G. Meguire (1985), "Macroeconomic Determinants of Growth: Cross-country Evidence", Journal of Monetary Economics, 16, 141-163.

64. Krishna, K., Ataman O., and Norman S. (2003), "Trade, investment and growth: nexus, analysis, and prognosis", Journal of Development Economics, 70, 479-99.

65. Krugman, P. (1988), "Market-based debt reduction schemes", NBER WP 2587.

66. Landau, D. (1983), "Government Expenditure and Economic Growth: A Cross Country Study”, Southern Economic Journal, 49, 783-792.

67. Landau, D. (1986), "Government and Economic Growth in the Less Developed Countries: An Empirical Study for 1960-1980", Economic Development and Cultural Change, 35(1), 35-75.

68. Larraín, F. and R. Vergara (1993), "Investment and Macroeconomic Adjustment: the Case of East Asia". In Striving for Growth After Adjustment: The Role of Capital Formation, L. Servén and A. Solimano (editors), The World Bank, Washington D.C.

69. Levine, Ross and David Renelt. (1992), "A Sensitivity Analysis of Cross-Country Growth Regressions," American Economic Review 82(4), 942-963.

70. Loungani, P. and Rush M. (1995), "The effect of changes in reserve requirements on investment and GNP", Journal of Money, Credit and Banking 27, 511-526.

71. Malik, A., Temple J. (2009), "The geography of output volatility", Journal of Development Economics, 90(2), 163-178.

72. Mehrotra, A. and Valila, T. (2006), "Public investment in Europe: evolution and determinants in perspective", Fiscal Studies, 27(4), 443-471.

73. Keynes, John M. [1936] 1973. The General Theory of Employment Interest and Money, vol. VII, The Collected Writings of John Maynard Keynes, edited by D.E. Moggridge (London: Macmillan).

74. Ndikumana, L. (2000), "Financial Determinants of Domestic Investment in Sub-Saharan Africa", World Development, 28 (2), 381-400.

75. Nelson, M.A. and R.D. Singh (1994), "Deficit-Growth Connection: Some Recent Evidence from Developing Countries", Economic Development and Cultural Change, 43(1), 167-91.

76. Oshikoya, Temitope W., 1994, "Macroeconomic Determinants of Domestic Private Investment in Africa: An Empirical Analysis," Economic Development and Cultural Change, Vol. 42, pp. 573-96.

77. Ozler, S., Rodrik, D., (1992), "External shocks, politics, and private investment: some theory and empirical evidence", Journal of Development Economics 39, 141-162.

78. Pesaran, M. H. (2006), "Estimation and inference in large heterogeneous panels with a multifactor error structure", Econometrica, 74(4), 967-1012.

79. Pesaran, M. H. (2007), "A simple panel unit root test in the presence of cross section dependence", Journal of Applied Econometrics, 22(2), 265-312.

80. Pesaran, M. H. (2009), "Weak and strong cross section dependence and estimation of large panels", Keynote speech, $5^{\text {th }}$ Nordic Econometric Meeting, Lund, $29^{\text {th }}$ October.

81. Pesaran, M. H., Tosetti, E. (2007), "Large panels with common factors and spatial correlations", CESIFO WP No. 2103 Kapetanios, G., Pesaran, M. H., Takashi, Y. (2009), "Panels with non-stationary multifactor error structures", unpublished working paper, updated version of IZA WP No. 2243. 
82. Pesaran, M.H. (2004), "General diagnostic tests for cross section dependence in panels", Cambridge Working Papers in Economics, 0435, University of Cambridge.

83. Pindyck, R. S. and Rubinfeld, D. L. (1991), "Econometric Models and Economic Forecasts", 2rd ed., NY, McGraw-Hill.

84. Prichett, L. (1996), "Mind Your p's and q's: the cost of public investment is not the value of public capital", World Bank Working Paper 1660.

85. Raftery, A. (1995), "Bayesian Model selection in social research", in Sociological Methodology, ed. Peter Marsden, Blackwells, Cambridge.

86. Roodman, D. (2009), "A Note on the Theme of Too Many Instruments", Oxford Bulletin of Economics and Statistics, 71(1), 135-158

87. Sakr, Khaled (1993) Determinants of Private Investment in Pakistan. Washington, D.C. (IMF Working Paper/93/30.)

88. Sala-i-Martin, X., Doppelhofer, G., Miller, R. (2004), "Determinants of long-run growth: A Bayesian Averaging Classical Estimates (BACE) approach", American Economic Review, 94(4), 813-835.

89. Sala-i-Martin, X. (1997), "I Have Just Run Two Million Regressions," American Economic Review 87(2), 178-183.

90. Sarafidis, V., Wansbeek, T. (2010), "Cross-sectional dependence in panel data analysis", MPRA WP 20367.

91. Savvides, A. 1995, 'Economic growth in Africa', World Development, 23(3), 449- 458.

92. Serven, L. and Solimano, A. (1991), "Adjustment policies and investment performance in developing countries: theory, country experiences and policy implications", Policy, Planning and Research, World Bank WP 606.

93. Servén, L., and A. Solimano (1993), "Private Investment and Macroeconomic Investment: A Survey." In L. Serven and A. Solimano editors, Striving for Growth after Adjustment: The Role of Capital Formation, The World Bank, Washington D.C., 11-30.

94. Siddiqui, R., and Siddiqui, R. (1993), "Household Saving Behaviour in Pakistan", The Pakistan Development Review 32(4), 1281-1292.

95. Solimano, A. (1989), "How Private Investment reacts to changing Macroeconomic Conditions. The case of Chile in the 1980s", World Bank Working Paper 212.

96. Sturm, J.-E. (1998), "Public capital expenditure in OECD countries: causes and consequences of the decline in public capital spending", Cheltenham: Edward Elgar.

97. Tornell, A. and Lane, P. R. (1999), "The voracity effect", American Economic Review, $89,22-46$.

98. Turrini, A. (2004), "Public investment and the EU fiscal framework", European Commission, DG for Economic and Financial Affairs, WP 202. 
Table 1a: BMA-Determinants of Private Investment

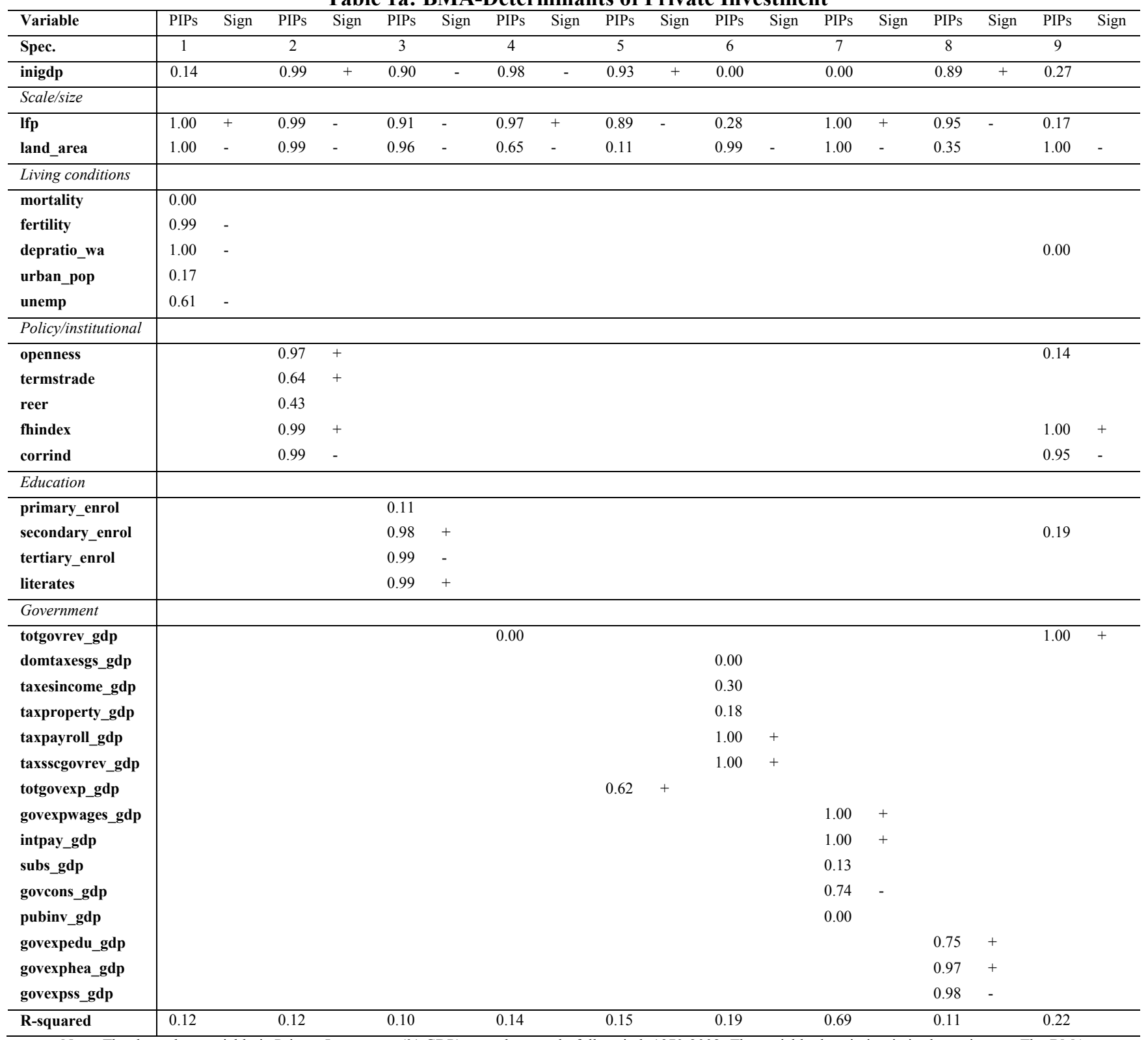

Note: The dependent variable is Private Investment (\% GDP) over the sample full period, 1970-2008. The variable description is in the main text. The BMA analysis yields the posterior probabilities of inclusion (PIPs) and the sign certainty index of a relationship. A sign is given to the PIPs greater than 0.5 . No sign means the sign of estimated relationship being uncertain. 
Table 1b: BMA-Determinants of Public Investment

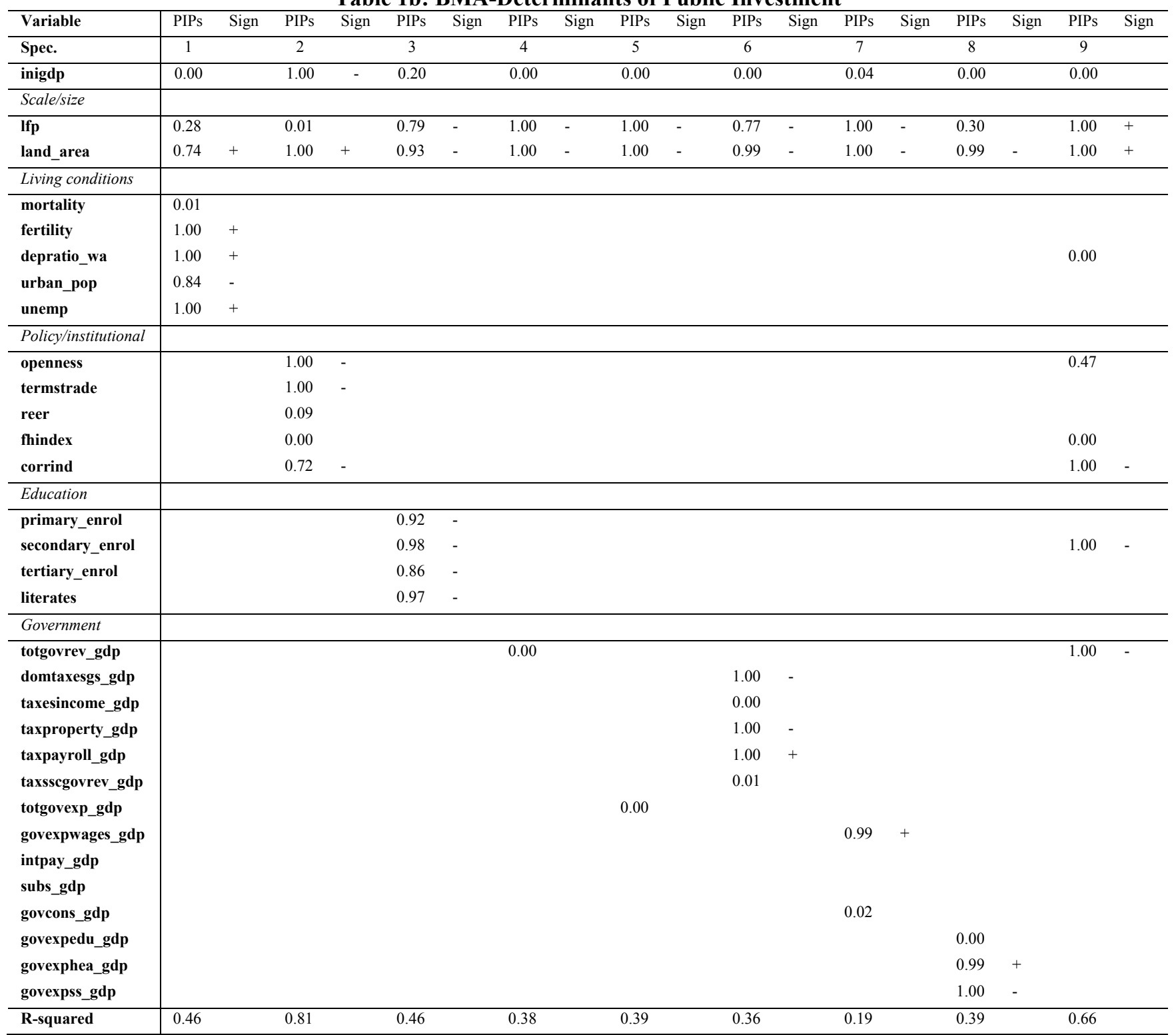

Note: The dependent variable is Public Investment (\% GDP) over the sample full period, 1970-2008. The variable description is in the main text. The BMA analysis yields the posterior probabilities of inclusion (PIPs) and the sign certainty index of a relationship. A sign is given to the PIPs greater than 0.5 . No sign means the sign of estimated relationship being uncertain.

Table 2: Top 5 BMA-type Models and their posterior probabilities

\begin{tabular}{l|cc}
\hline Dependent variable & Priinv & Pubinv \\
\hline Regressors & $*$ & $*, \mathrm{~s}$ \\
inigdppc & $*, \mathrm{~s}$ & $*$ \\
laborf & $*, \mathrm{~s}$ & $*, \mathrm{~s}$ \\
landarea & & $*, \mathrm{~s}$ \\
openness & & $*, \mathrm{~s}$ \\
termstrade & & $*$ \\
reer & & $*$ \\
fhindex & & $*, \mathrm{~s}$ \\
corrind & $*, \mathrm{~s}$ & \\
govexpwages_gdp & $*, \mathrm{~s}$ & \\
intpay_gdp & $*$, & \\
subs_gdp & $*, \mathrm{~s}$ & \\
govcons_gdp & $*$ & \\
pubinv_gdp & 0.69 & 0.81 \\
\hline$R$-squared &
\end{tabular}


Note: This table presents the top models from Tables $1 \mathrm{a}-1 \mathrm{~b}$, ranked by their R-squares in the whole sample. The variable description is in the main text. * and $\mathrm{s}$, denote inclusion of the variable in the BMA regression and whether it reported a statistically significant coefficient, respectively.

Table 3: Benchmark cross-country investment equations, 5-year averages (including time period dummies) - Fixed Effects and System-GMM

\begin{tabular}{|c|c|c|c|c|c|c|c|c|c|c|c|c|}
\hline Dependent & \multicolumn{3}{|c|}{ Private Investment } & \multicolumn{3}{|c|}{ Public Investment } & \multicolumn{3}{|c|}{ Private Investment } & \multicolumn{3}{|c|}{ Public Investment } \\
\hline Estimation & \multicolumn{6}{|c|}{ FE (within) } & \multicolumn{6}{|c|}{ SYS-GMM } \\
\hline Sample & All & OECD & Emerg & All & OECD & Emerg & All & OECD & Emerg & All & OECD & Emerg \\
\hline Spec. & 1 & 2 & 3 & 4 & 5 & 6 & 7 & 8 & 9 & 10 & 11 & 12 \\
\hline Equation & & $I .1$ & & & $I .2$ & & & $I .1$ & & & $I .2$ & \\
\hline \multirow[t]{2}{*}{ inigdppc } & -0.70 & - & $-4.25 * *$ & 1.11 & -1.16 & $-3.24 * *$ & $-1.49 * *$ & $-2.48 * *$ & $-3.80^{*}$ & - & - & - \\
\hline & $(0.959)$ & $\begin{array}{l}5.42 \\
(1.477)\end{array}$ & (1.579) & $(0.877)$ & $(0.853)$ & $(1.333)$ & $(0.611)$ & $(0.968)$ & $(2.227)$ & $\begin{array}{l}2.81 \\
(0.812)\end{array}$ & $\begin{array}{l}4 . / 0^{2} \\
(1.794)\end{array}$ & $(1.028)$ \\
\hline \multirow[t]{2}{*}{ Ifp } & 0.03 & 0.17 & 0.06 & 0.01 & 0.10 & 0.05 & -0.22 & 0.09 & -0.18 & $-0.23 * *$ & 0.15 & -0.15 \\
\hline & $(0.080)$ & $(0.102)$ & $(0.087)$ & $(0.072)$ & $(0.062)$ & $(0.168)$ & $(0.135)$ & $(0.144)$ & $(0.144)$ & $(0.099)$ & $(0.167)$ & $(0.098)$ \\
\hline \multirow[t]{2}{*}{ popgr } & $1.27 * * *$ & $2.34 * * *$ & $1.64^{* * *}$ & 0.41 & 0.75 & -0.53 & 0.65 & $2.77 * * *$ & $1.38 * *$ & 0.02 & -0.34 & -0.66 \\
\hline & $(0.357)$ & $(0.733)$ & $(0.509)$ & $(0.295)$ & $(0.476)$ & $(0.941)$ & $(0.670)$ & (1.071) & $(0.647)$ & $(0.325)$ & $(1.072)$ & $(1.051)$ \\
\hline \multirow[t]{2}{*}{ depratio_wa } & -0.01 & $-0.16^{* *}$ & 0.04 & $0.13 * * *$ & 0.05 & $0.22 * * *$ & - & - & - & $0.10^{*}$ & -0.11 & -0.08 \\
\hline & $(0.037)$ & & $(0.051)$ & & $(0.051)$ & & $\begin{array}{l}0.24 * * * \\
(0.054)\end{array}$ & $\begin{array}{l}0.31^{* * * *} \\
(0.079)\end{array}$ & $\begin{array}{l}0.31 * * * * \\
(0.097)\end{array}$ & $(0.056)$ & $(0.117)$ & \\
\hline Obs. & 1,007 & 202 & 197 & 488 & 146 & 99 & 1,007 & 202 & 197 & 488 & 146 & 99 \\
\hline$R$-squared & 0.03 & 0.23 & 0.17 & 0.07 & 0.19 & 0.31 & & & & & & \\
\hline $\begin{array}{l}\text { Hansen ( } p \text { - } \\
\text { value) }\end{array}$ & & & & & & & 0.03 & 1.00 & 1.00 & 0.36 & 1.00 & 1.00 \\
\hline $\begin{array}{l}A B A R(1)(p- \\
\text { value) }\end{array}$ & & & & & & & 0.62 & 0.93 & 0.69 & 0.17 & 0.16 & 0.57 \\
\hline $\begin{array}{l}A B A R(2)(p- \\
\text { value })\end{array}$ & & & & & & & 0.08 & 0.04 & 0.22 & 0.07 & 0.35 & 0.42 \\
\hline
\end{tabular}

Note: The models are estimated by either Within Fixed Effects (FE-within) or Two-Step robust System GMM (SYS-GMM). For the latter method lagged regressors are used as suitable instruments. The dependent variable is either private investment or public investment,. Robust heteroskedastic-consistent standard errors are reported in parenthesis below each coefficient estimate. The Hansen test evaluates the validity of the instrument set, i.e., tests for over-identifying restrictions. AR(1) and AR(2) are the Arellano-Bond autocorrelation tests of first and second order (the null is no autocorrelation), respectively. A constant term has been estimated but it is not reported for reasons of parsimony. ${ }^{*}, *, * * *$ denote significance at 10,5 and $1 \%$ levels.

Table 4: Investment equations with Budgetary Economic Decomposition when fiscal variables are introduced one at a time in the benchmark equations, 5-year averages

\begin{tabular}{|c|c|c|c|c|c|c|c|c|}
\hline \multirow{3}{*}{$\begin{array}{c}\text { Dependent Variable } \\
\text { Estimation } \\
\text { Sample } \\
\end{array}$} & \multicolumn{3}{|c|}{ Private Investment } & \multicolumn{3}{|c|}{ Public Investment } & $\begin{array}{c}\text { Private } \\
\text { Investment }\end{array}$ & $\begin{array}{c}\text { Public } \\
\text { Investment }\end{array}$ \\
\hline & \multicolumn{6}{|c|}{ Fixed Effects (within) } & \multicolumn{2}{|c|}{ SYS-GMM } \\
\hline & All & OECD & All & All & OECD & Emerg & \multicolumn{2}{|c|}{ All } \\
\hline Spec. & 1 & 2 & 7 & 8 & 5 & 6 & 7 & 8 \\
\hline Equation & & I.1 & & & $I .2$ & & I.1 & $I .2$ \\
\hline$\underline{\text { Revenue Variables }}$ & & & & & & & & \\
\hline taxrev_gdp & $\begin{array}{c}0.28 \\
(0.238)\end{array}$ & $\begin{array}{c}0.24 \\
(0.186)\end{array}$ & $\begin{array}{l}1.09 * * * \\
(0.260)\end{array}$ & $\begin{array}{c}0.14 \\
(0.287)\end{array}$ & $\begin{array}{c}-0.07 \\
(0.098)\end{array}$ & $\begin{array}{c}0.01 \\
(0.286)\end{array}$ & $\begin{array}{c}0.47 \\
(0.352)\end{array}$ & $\begin{array}{c}0.03 \\
(0.333)\end{array}$ \\
\hline domtaxesgs_gdp & $\begin{array}{l}-0.10 \\
(0.265)\end{array}$ & $\begin{array}{l}-0.21 \\
(0.344)\end{array}$ & $\begin{array}{c}-0.23 \\
(0.393)\end{array}$ & $\begin{array}{c}0.01 \\
(0.239)\end{array}$ & $\begin{array}{c}0.04 \\
(0.186)\end{array}$ & $\begin{array}{l}-0.27 \\
(0.298)\end{array}$ & $\begin{array}{l}-0.15 \\
(0.570)\end{array}$ & $\begin{array}{c}-0.12 \\
(0.368)\end{array}$ \\
\hline taxesincome_gdp & $\begin{array}{l}0.21^{*} \\
(0.120)\end{array}$ & $\begin{array}{l}-0.03 \\
(0.109)\end{array}$ & $\begin{array}{c}0.26 \\
(0.350)\end{array}$ & $\begin{array}{l}0.42 * * * \\
(0.092)\end{array}$ & $\begin{array}{c}0.11 \\
(0.084)\end{array}$ & $\begin{array}{l}0.35^{* *} \\
(0.147)\end{array}$ & $\begin{array}{l}0.56 * * \\
(0.253)\end{array}$ & $\begin{array}{c}0.41^{*} \\
(0.241)\end{array}$ \\
\hline taxproperty_gdp & $\begin{array}{l}1.32 \\
(0.936)\end{array}$ & $\begin{array}{c}0.23 \\
(0.622)\end{array}$ & $\begin{array}{c}0.49 \\
(2.691)\end{array}$ & $\begin{array}{c}0.24 \\
(0.613)\end{array}$ & $\begin{array}{l}-0.47 \\
(0.422)\end{array}$ & $\begin{array}{c}0.85 \\
(1.197)\end{array}$ & $\begin{array}{c}0.34 \\
(1.352)\end{array}$ & $\begin{array}{c}0.47 \\
(2.189)\end{array}$ \\
\hline taxpayroll_gdp & $\begin{array}{c}0.36 \\
(1.317)\end{array}$ & $\begin{array}{c}1.06 \\
(0.899)\end{array}$ & $\begin{array}{l}-9.30^{*} \\
(4.687)\end{array}$ & $\begin{array}{c}0.64 \\
(0.673)\end{array}$ & $\begin{array}{l}-0.29 \\
(0.417)\end{array}$ & $\begin{array}{c}0.75 \\
(1.398)\end{array}$ & $\begin{array}{l}1.91 \\
(1.281)\end{array}$ & $\begin{array}{c}0.96 \\
(2.018)\end{array}$ \\
\hline taxsscgovrev_gdp & $\begin{array}{c}0.13 \\
(0.093)\end{array}$ & $\begin{array}{c}-0.01 \\
(0.083) \\
\end{array}$ & $\begin{array}{c}-0.13 \\
(0.171) \\
\end{array}$ & $\begin{array}{c}0.26^{* * *} \\
(0.089) \\
\end{array}$ & $\begin{array}{c}0.01 \\
(0.050) \\
\end{array}$ & $\begin{array}{l}0.28^{*} \\
(0.142)\end{array}$ & $\begin{array}{c}0.22 \\
(0.163) \\
\end{array}$ & $\begin{array}{c}0.29 \\
(0.177) \\
\end{array}$ \\
\hline $\begin{array}{l}\text { Expenditure Variables } \\
\text { govexpwages_gdp }\end{array}$ & -0.18 & -0.26 & -0.18 & 0.02 & 0.11 & -0.24 & 0.28 & $0.32 * *$ \\
\hline & $(0.144)$ & $(0.226)$ & $(0.184)$ & $(0.098)$ & $(0.152)$ & $(0.304)$ & $(0.374)$ & $(0.131)$ \\
\hline intpay_gdp & $\begin{array}{c}0.01 \\
(0.028)\end{array}$ & $\begin{array}{l}-0.18 \\
(0.226)\end{array}$ & $\begin{array}{c}-0.02 * * * \\
(0.005)\end{array}$ & $\begin{array}{c}-0.02 * * * \\
(0.007)\end{array}$ & $\begin{array}{c}-0.55 * * * \\
(0.091)\end{array}$ & $\begin{array}{l}-0.01 * * \\
(0.006)\end{array}$ & $\begin{array}{l}-0.03 * * \\
(0.015)\end{array}$ & $\begin{array}{l}-0.03 \\
(0.026)\end{array}$ \\
\hline subs_gdp & $\begin{array}{c}0.00 \\
(0.004)\end{array}$ & $\begin{array}{c}0.04 \\
(0.038)\end{array}$ & $\begin{array}{l}0.01 * * * \\
(0.001)\end{array}$ & $\begin{array}{c}-0.01 * * * \\
(0.002)\end{array}$ & $\begin{array}{l}-0.04 * * \\
(0.014)\end{array}$ & $\begin{array}{l}-0.00 * * \\
(0.002)\end{array}$ & $\begin{array}{c}-0.00 \\
(0.008)\end{array}$ & $\begin{array}{l}-0.01^{*} \\
(0.006)\end{array}$ \\
\hline govcons_gdp & $\begin{array}{c}-0.04 \\
(0.070)\end{array}$ & $\begin{array}{l}-0.16 \\
(0.143)\end{array}$ & $\begin{array}{c}0.01 \\
(0.104)\end{array}$ & $\begin{array}{c}0.21 * * * \\
(0.056)\end{array}$ & $\begin{array}{l}0.16^{* *} \\
(0.064)\end{array}$ & $\begin{array}{c}0.12 \\
(0.104)\end{array}$ & $\begin{array}{c}-0.06 \\
(0.208)\end{array}$ & $\begin{array}{l}0.31 * * \\
(0.138)\end{array}$ \\
\hline
\end{tabular}

Note: The models are estimated by either Within Fixed Effects (FE-within) or system GMM (SYS-GMM). For the latter method lagged regressors are used as suitable instruments. The dependent variable is either private investment or public investment. Different individual regressions using the set of regressors and controls present in table 4. (in bold) were performed and only coefficients of interest are reported for economy of space. Revenue and expenditure variables were included individually in each regression. Full results are available from the authors upon request. Robust heteroskedastic-consistent standard errors are reported in parenthesis below each coefficient estimate. Time fixed effects were included, but are not reported. Also a constant term has been estimated but it is not reported for reasons of parsimony. ${ }^{*}, * * * *$ denote significance at 10,5 and $1 \%$ levels. 
Table 5a: Investment equations with Decomposition of Government Revenues, 5-year averages - Fixed Effects and System-GMM

\begin{tabular}{|c|c|c|c|c|c|c|c|c|}
\hline Dependent Variable & \multicolumn{3}{|c|}{ Private Investment } & \multicolumn{3}{|c|}{ Public Investment } & $\begin{array}{c}\text { Private } \\
\text { Investment }\end{array}$ & $\begin{array}{c}\text { Public } \\
\text { Investment }\end{array}$ \\
\hline Estimation & & & & & & & \multicolumn{2}{|c|}{ SYS-GMM } \\
\hline Sample & All & OECD & Emerg & All & OECD & Emerg & \multicolumn{2}{|c|}{ All } \\
\hline Spec. & 1 & 2 & 3 & 4 & 5 & 6 & 7 & 8 \\
\hline Equation & & $I .1$ & & & $I .2$ & & $I .1$ & $I .2$ \\
\hline inigdppc & $\begin{array}{c}-2.20 \\
(3.060)\end{array}$ & $\begin{array}{c}-9.06 * * * \\
(2.826)\end{array}$ & $\begin{array}{c}28.93 \\
(17.497)\end{array}$ & $\begin{array}{c}2.74 \\
(2.132)\end{array}$ & $\begin{array}{c}-3.03 * * * \\
(0.613)\end{array}$ & $\begin{array}{l}8.53 * * \\
(3.021)\end{array}$ & $\begin{array}{c}-0.91 \\
(1.911)\end{array}$ & $\begin{array}{l}-2.88 * * \\
(1.186)\end{array}$ \\
\hline Ifp & $\begin{array}{c}-0.03 \\
(0.189)\end{array}$ & $\begin{array}{c}0.08 \\
(0.290)\end{array}$ & $\begin{array}{c}0.01 \\
(0.225)\end{array}$ & $\begin{array}{c}0.09 \\
(0.112)\end{array}$ & $\begin{array}{c}0.01 \\
(0.021)\end{array}$ & $\begin{array}{l}0.30^{* *} \\
(0.110)\end{array}$ & $\begin{array}{l}-0.06 \\
(0.178)\end{array}$ & $\begin{array}{c}-0.08 \\
(0.113)\end{array}$ \\
\hline popgr & $\begin{array}{c}4.30 * * * \\
(0.975)\end{array}$ & $\begin{array}{l}3.52 * * \\
(1.433)\end{array}$ & $\begin{array}{l}11.91 * * \\
(4.620)\end{array}$ & $\begin{array}{c}0.83 \\
(0.757)\end{array}$ & $\begin{array}{l}1.04 * * * \\
(0.302)\end{array}$ & $\begin{array}{c}-0.25 \\
(1.913)\end{array}$ & $\begin{array}{c}4.69 * * * \\
(1.573)\end{array}$ & $\begin{array}{c}1.61 \\
(1.058)\end{array}$ \\
\hline depratio_wa & $\begin{array}{c}0.05 \\
(0.078)\end{array}$ & $\begin{array}{c}-0.04 \\
(0.081)\end{array}$ & $\begin{array}{c}-0.13 \\
(0.119)\end{array}$ & $\begin{array}{c}0.18^{* * *} \\
(0.056)\end{array}$ & $\begin{array}{c}0.11 * * * \\
(0.032)\end{array}$ & $\begin{array}{c}0.27 * * * \\
(0.069)\end{array}$ & $\begin{array}{c}-0.39 * * * \\
(0.115)\end{array}$ & $\begin{array}{c}-0.04 \\
(0.090)\end{array}$ \\
\hline$\underline{\text { Revenue Variables }}$ & & & & & & & & \\
\hline domtaxesgs_gdp & $\begin{array}{c}-0.40 \\
(0.402)\end{array}$ & $\begin{array}{c}-0.00 \\
(0.363)\end{array}$ & $\begin{array}{c}-2.86^{*} \\
(1.501)\end{array}$ & $\begin{array}{c}-0.19 \\
(0.407)\end{array}$ & $\begin{array}{c}-0.00 \\
(0.258)\end{array}$ & $\begin{array}{c}-0.76 \\
(0.417)\end{array}$ & $\begin{array}{c}-0.35 \\
(0.689)\end{array}$ & $\begin{array}{c}-0.06 \\
(0.304)\end{array}$ \\
\hline taxesincome_gdp & $\begin{array}{c}0.96 * * * \\
(0.351)\end{array}$ & $\begin{array}{c}-0.23 \\
(0.567)\end{array}$ & $\begin{array}{c}-4.82 \\
(2.891)\end{array}$ & $\begin{array}{c}0.77 * * * \\
(0.189)\end{array}$ & $\begin{array}{c}0.29 * * * \\
(0.072)\end{array}$ & $\begin{array}{c}-1.33 \\
(0.997)\end{array}$ & $\begin{array}{c}0.47 \\
(0.685)\end{array}$ & $\begin{array}{l}0.35^{* *} \\
(0.177)\end{array}$ \\
\hline taxproperty_gdp & $\begin{array}{c}0.66 \\
(1.142)\end{array}$ & $\begin{array}{c}-0.65 \\
(0.776)\end{array}$ & $\begin{array}{c}-36.29 * * \\
(15.715)\end{array}$ & $\begin{array}{c}0.27 \\
(0.708)\end{array}$ & $\begin{array}{c}2.11 \\
(4.479)\end{array}$ & $\begin{array}{c}-5.62 \\
(3.033)\end{array}$ & $\begin{array}{c}1.16 \\
(1.925)\end{array}$ & $\begin{array}{c}1.31 \\
(1.189)\end{array}$ \\
\hline taxpayroll_gdp & $\begin{array}{c}1.80 \\
(1.226)\end{array}$ & $\begin{array}{c}0.75 \\
(0.972)\end{array}$ & $\begin{array}{c}-13.62 \\
(12.730)\end{array}$ & $\begin{array}{c}1.16 \\
(0.865)\end{array}$ & $\begin{array}{c}-0.38 \\
(0.508)\end{array}$ & $\begin{array}{l}5.14 * * \\
(2.095)\end{array}$ & $\begin{array}{c}-0.86 \\
(2.323)\end{array}$ & $\begin{array}{c}-0.41 \\
(1.180)\end{array}$ \\
\hline taxsscgovrev_gdp & $\begin{array}{c}-0.38^{*} \\
(0.203)\end{array}$ & $\begin{array}{c}0.14 \\
(0.152)\end{array}$ & $\begin{array}{c}1.99 \\
(1.783)\end{array}$ & $\begin{array}{c}0.34 * * * \\
(0.113)\end{array}$ & $\begin{array}{c}-0.05 \\
(0.079)\end{array}$ & $\begin{array}{c}0.14 \\
(0.533)\end{array}$ & $\begin{array}{c}0.17 \\
(0.477)\end{array}$ & $\begin{array}{c}0.25 \\
(0.159)\end{array}$ \\
\hline Obs. & 164 & 54 & 31 & 131 & 58 & 27 & 164 & 131 \\
\hline$R$-squared & 0.30 & 0.50 & 0.66 & 0.38 & 0.40 & 0.92 & & \\
\hline Hansen (p-value) & & & & & & & 0.97 & 1.00 \\
\hline$A B A R(1)$ (p-value) & & & & & & & 0.23 & 0.65 \\
\hline$A B A R(2)(p$-value $)$ & & & & & & & 0.61 & 0.56 \\
\hline
\end{tabular}

Note: The models are estimated by either Within Fixed Effects (FE-within) or Two-Step robust System GMM (SYS-GMM). For the latter method lagged regressors are used as suitable instruments. The dependent variable is either private investment or public investment. Robust heteroskedastic-consistent standard errors are reported in parenthesis below each coefficient estimate. The Hansen test evaluates the validity of the instrument set, i.e., tests for over-identifying restrictions. AR(1) and AR(2) are the Arellano-Bond autocorrelation tests of first and second order (the null is no autocorrelation), respectively. A constant term has been estimated but it is not reported for reasons of parsimony. $* * *, * * *$ denote significance at 10,5 and $1 \%$ levels.

Table 5b: Investment equations with Decomposition of Government Expenditures, 5-year averages - Fixed Effects and System-GMM

\begin{tabular}{|c|c|c|c|c|c|c|c|c|}
\hline \multirow{4}{*}{$\begin{array}{c}\text { Dependent Variable } \\
\text { Estimation } \\
\text { Sample } \\
\text { Spec. }\end{array}$} & \multicolumn{3}{|c|}{ Private Investment } & \multicolumn{3}{|c|}{ Public Investment } & $\begin{array}{c}\text { Private } \\
\text { Investment }\end{array}$ & $\begin{array}{c}\text { Public } \\
\text { Investment }\end{array}$ \\
\hline & \multicolumn{6}{|c|}{ FE (within) } & \multirow{2}{*}{\multicolumn{2}{|c|}{ SYS-GMM }} \\
\hline & All & OECD & Emerg & All & OECD & Emerg & & \\
\hline & 1 & 2 & 3 & 4 & 5 & 6 & 7 & 8 \\
\hline Equation & & I.1 & & & $I .2$ & & I.1 & $I .2$ \\
\hline inigdppc & $\begin{array}{c}2.92 \\
(2.795)\end{array}$ & $\begin{array}{c}-3.65 \\
(3.344)\end{array}$ & $\begin{array}{c}0.15 \\
(5.477)\end{array}$ & $\begin{array}{c}0.98 \\
(2.413)\end{array}$ & $\begin{array}{c}-0.70 \\
(0.676)\end{array}$ & $\begin{array}{c}3.98^{*} \\
(1.956)\end{array}$ & $\begin{array}{c}-2.34 * \\
(1.290)\end{array}$ & $\begin{array}{l}-3.94 * \\
(2.333)\end{array}$ \\
\hline Ifp & $\begin{array}{c}-0.07 \\
(0.203)\end{array}$ & $\begin{array}{c}0.75 * * * \\
(0.236)\end{array}$ & $\begin{array}{c}-0.01 \\
(0.363)\end{array}$ & $\begin{array}{l}0.39 * * \\
(0.176)\end{array}$ & $\begin{array}{c}0.09 \\
(0.069)\end{array}$ & $\begin{array}{c}0.51 * * * \\
(0.094)\end{array}$ & $\begin{array}{c}0.06 \\
(0.184)\end{array}$ & $\begin{array}{c}0.15 \\
(0.134)\end{array}$ \\
\hline popgr & $\begin{array}{c}1.04 \\
(0.651)\end{array}$ & $\begin{array}{l}2.65 * * \\
(1.264)\end{array}$ & $\begin{array}{c}6.54 \\
(4.416)\end{array}$ & $\begin{array}{c}0.40 * * * \\
(0.149)\end{array}$ & $\begin{array}{c}0.23 \\
(0.252)\end{array}$ & $\begin{array}{c}-1.30 \\
(1.320)\end{array}$ & $\begin{array}{c}0.85 \\
(0.847)\end{array}$ & $\begin{array}{c}0.57 \\
(0.545)\end{array}$ \\
\hline depratio_wa & $\begin{array}{c}-0.12 \\
(0.097)\end{array}$ & $\begin{array}{c}-0.07 \\
(0.080)\end{array}$ & $\begin{array}{c}-0.43 \\
(0.398)\end{array}$ & $\begin{array}{c}0.13 \\
(0.092)\end{array}$ & $\begin{array}{l}0.11^{* *} \\
(0.043)\end{array}$ & $\begin{array}{c}0.49 * * * \\
(0.108)\end{array}$ & $\begin{array}{c}-0.06 \\
(0.108)\end{array}$ & $\begin{array}{c}-0.20 \\
(0.150)\end{array}$ \\
\hline Expenditure Variables & & & & & & & & \\
\hline govexpwages_gdp & $\begin{array}{c}-0.35 \\
(0.226)\end{array}$ & $\begin{array}{c}0.47^{*} \\
(0.240)\end{array}$ & $\begin{array}{c}-0.43 \\
(0.450)\end{array}$ & $\begin{array}{c}0.88 \\
(0.687)\end{array}$ & $\begin{array}{c}0.15 \\
(0.126)\end{array}$ & $\begin{array}{l}-0.90^{*} \\
(0.432)\end{array}$ & $\begin{array}{c}0.07 \\
(0.279)\end{array}$ & $\begin{array}{c}0.38^{*} \\
(0.231)\end{array}$ \\
\hline intpay_gdp & $\begin{array}{c}-0.08 \\
(0.147)\end{array}$ & $\begin{array}{c}-3.63 * * * \\
(0.883)\end{array}$ & $\begin{array}{c}-1.53 \\
(1.010)\end{array}$ & $\begin{array}{c}-0.16 \\
(0.166)\end{array}$ & $\begin{array}{c}-1.31 * * * \\
(0.108)\end{array}$ & $\begin{array}{c}-1.89 * * * \\
(0.337)\end{array}$ & $\begin{array}{c}-0.47 * * * \\
(0.178)\end{array}$ & $\begin{array}{l}-0.15^{*} \\
(0.086)\end{array}$ \\
\hline subs_gdp & $\begin{array}{c}0.02 \\
(0.051)\end{array}$ & $\begin{array}{c}0.39 * * * \\
(0.133)\end{array}$ & $\begin{array}{c}0.52 \\
(0.346)\end{array}$ & $\begin{array}{c}0.05 \\
(0.058)\end{array}$ & $\begin{array}{c}-0.10 * * * \\
(0.022)\end{array}$ & $\begin{array}{c}-0.65 * * * \\
(0.118)\end{array}$ & $\begin{array}{c}0.17 * * * \\
(0.066)\end{array}$ & $\begin{array}{l}-0.05^{*} \\
(0.027)\end{array}$ \\
\hline govcons_gdp & $\begin{array}{c}-0.26 \\
(0.184)\end{array}$ & $\begin{array}{c}-0.07 \\
(0.301)\end{array}$ & $\begin{array}{c}-0.43 \\
(0.392)\end{array}$ & $\begin{array}{c}-0.01 \\
(0.096)\end{array}$ & $\begin{array}{c}0.14 \\
(0.086)\end{array}$ & $\begin{array}{c}0.05 \\
(0.243)\end{array}$ & $\begin{array}{c}0.25 \\
(0.309)\end{array}$ & $\begin{array}{c}0.38 \\
(0.309)\end{array}$ \\
\hline Obs. & 221 & 75 & 48 & 117 & 59 & 23 & 221 & 117 \\
\hline$R$-squared & 0.19 & 0.62 & 0.29 & 0.11 & 0.60 & 0.96 & & \\
\hline Hansen (p-value) & & & & & & & 0.32 & 1.00 \\
\hline$A B A R(1)$ (p-value) & & & & & & & 0.88 & 0.56 \\
\hline$A B A R(2)(p$-value $)$ & & & & & & & 1.00 & 0.71 \\
\hline
\end{tabular}

Note: The models are estimated by either Within Fixed Effects (FE-within) or Two-Step robust System GMM (SYS-GMM). For the latter method lagged regressors are used as suitable instruments. The dependent variable is either private investment or public investment,. Robust heteroskedastic-consistent standard errors are reported in parenthesis below each coefficient estimate. The Hansen test evaluates the validity of the instrument set, i.e., tests for over-identifying restrictions. AR(1) and $\mathrm{AR}(2)$ are the Arellano-Bond autocorrelation tests of first and second order (the null is no autocorrelation), respectively. A constant term has been estimated but it is not reported for reasons of parsimony. ${ }^{*}, * * * *$ denote significance at 10,5 and $1 \%$ levels. 
Table 6: Private Investment equation with Functional Decomposition of Public Expenditure when fiscal variables are introduced simultaneously (Panel $A)$ and one at a time (Panel B), 5-year averages

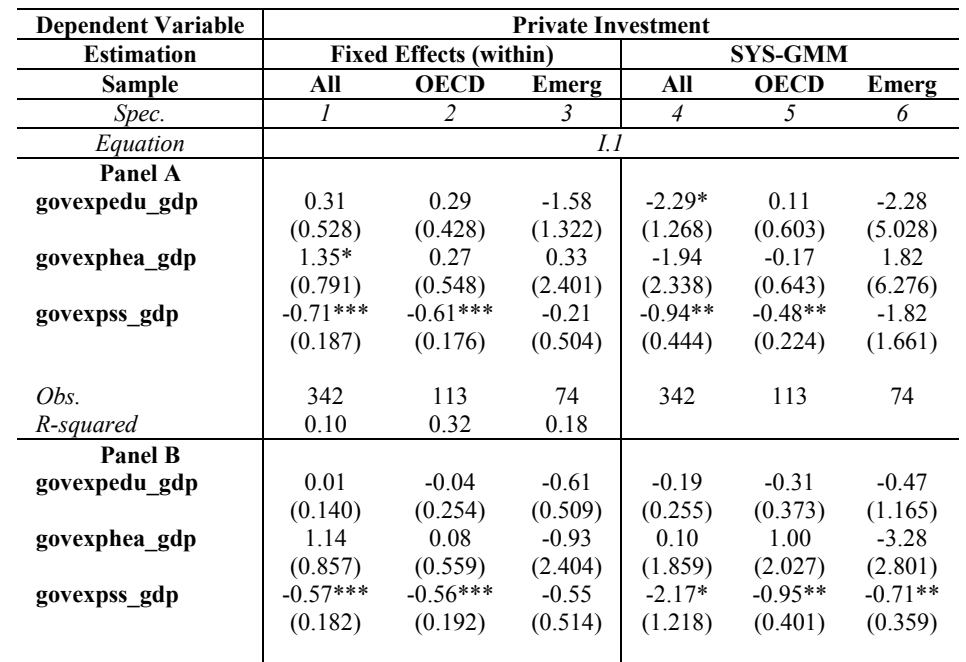

Note: The models are estimated by either Within Fixed Effects (FE-within) or system-GMM (SYS-GMM). For the latter method lagged regressors are used as suitable instruments. The dependent variable is private investment. Different individual regressions using the set of regressors and controls present in table 3 . (in bold) were performed and only coefficients of interested are reported for economy of space. Expenditure components (education, health and social security) were included individually in each regression. Full results are available from the authors upon request. Robust heteroskedastic-consistent standard errors are reported in parenthesis below each coefficient estimate. Time fixed effects were included, but are not reported. Also a constant term has been estimated but it is not reported for reasons of parsimony. $* * *, * *$ denote significance at 10,5 and $1 \%$ levels.

Table 7: Benchmark cross-country public investment equation with Budgetary Decomposition of Public Budget Balance (Revenue and Expenditure), 5-year averages - different samples with nonlinear effects of fiscal policy, according to the 3\% Budget Deficit threshold

\begin{tabular}{|c|c|c|c|c|c|c|}
\hline Dependent Variable & \multicolumn{6}{|c|}{ Public Investment } \\
\hline \multirow{3}{*}{$\begin{array}{c}\text { Estimation } \\
\text { Sample } \\
\end{array}$} & & & Fixed Eff & s (within & & \\
\hline & \multicolumn{6}{|c|}{ All } \\
\hline & $>3 \%$ & $<3 \%$ & $>3 \%$ & $<3 \%$ & $>3 \%$ & $<3 \%$ \\
\hline Spec. & 1 & 2 & 3 & 4 & 5 & 6 \\
\hline inigdppc & $\begin{array}{c}-0.73 \\
(1.475)\end{array}$ & $\begin{array}{l}2.17^{* *} \\
(0.994)\end{array}$ & $\begin{array}{c}2.23 \\
(3.051)\end{array}$ & $\begin{array}{c}1.02 \\
(2.562)\end{array}$ & $\begin{array}{c}1.40 \\
(2.134)\end{array}$ & $\begin{array}{c}2.75 \\
(4.168)\end{array}$ \\
\hline Ifp & $\begin{array}{c}0.16 \\
(0.138)\end{array}$ & $\begin{array}{c}-0.05 \\
(0.084)\end{array}$ & $\begin{array}{c}0.20 \\
(0.209)\end{array}$ & $\begin{array}{l}-0.08 \\
(0.143)\end{array}$ & $\begin{array}{l}-0.04 \\
(0.166)\end{array}$ & $\begin{array}{c}0.59^{*} \\
(0.321)\end{array}$ \\
\hline popgr & $\begin{array}{l}1.05^{* *} \\
(0.430)\end{array}$ & $\begin{array}{c}0.36 \\
(0.400)\end{array}$ & $\begin{array}{c}1.12 \\
(1.132)\end{array}$ & $\begin{array}{r}4.35^{* * *} \\
(1.163)\end{array}$ & $\begin{array}{c}0.07 \\
(0.728)\end{array}$ & $\begin{array}{l}0.42 * * \\
(0.165)\end{array}$ \\
\hline depratio_wa & $\begin{array}{c}0.18^{* * *} \\
(0.044)\end{array}$ & $\begin{array}{l}0.10^{* *} \\
(0.042)\end{array}$ & $\begin{array}{c}0.26^{* * * *} \\
(0.070)\end{array}$ & $\begin{array}{c}-0.18 \\
(0.141)\end{array}$ & $\begin{array}{c}0.01 \\
(0.070)\end{array}$ & $\begin{array}{c}0.15 \\
(0.194)\end{array}$ \\
\hline$\frac{\text { Revenue Variables }}{\text { domtaxesgs_gdp }}$ & & & $\begin{array}{c}0.32 \\
(0.393)\end{array}$ & $\begin{array}{l}-0.87^{*} \\
(0.484)\end{array}$ & & \\
\hline taxesincome_gdp & & & $\begin{array}{l}1.05^{* *} \\
(0.379)\end{array}$ & $\begin{array}{c}0.21 \\
(0.355)\end{array}$ & & \\
\hline taxproperty_gdp & & & $\begin{array}{c}0.64 \\
(0.586)\end{array}$ & $\begin{array}{c}-0.56 \\
(2.735)\end{array}$ & & \\
\hline taxpayroll_gdp & & & $\begin{array}{c}0.72 \\
(1.366)\end{array}$ & $\begin{array}{c}2.21 \\
(1.426)\end{array}$ & & \\
\hline taxsscgovrev_gdp & & & $\begin{array}{c}-0.38^{* * * *} \\
(0.126)\end{array}$ & $\begin{array}{l}-0.07 \\
(0.312)\end{array}$ & & \\
\hline $\begin{array}{l}\text { Expenditure Variables } \\
\text { govexpwages_gdp }\end{array}$ & & & & & $\begin{array}{c}0.14 \\
(0.206)\end{array}$ & $\begin{array}{c}2.13 \\
(2.024)\end{array}$ \\
\hline intpay_gdp & & & & & $\begin{array}{c}-1.79 * * * \\
(0.545)\end{array}$ & $\begin{array}{l}-0.20 \\
(0.360)\end{array}$ \\
\hline subs_gdp & & & & & $\begin{array}{l}-2.47 * * \\
(1.114)\end{array}$ & $\begin{array}{c}0.07 \\
(0.126)\end{array}$ \\
\hline govcons_gdp & & & & & $\begin{array}{c}-0.16^{* *} \\
(0.073)\end{array}$ & $\begin{array}{c}0.25 \\
(0.305)\end{array}$ \\
\hline & 205 & 252 & 61 & 61 & 52 & 63 \\
\hline$R$-squared & 0.20 & 0.05 & 0.60 & 0.49 & 0.34 & 0.21 \\
\hline
\end{tabular}

Note: The models are estimated by Within Fixed Effects (FE-within). "Above" and "below" performers are classified as those having maintained an average (over the country's time span) budget deficit below $3 \%$ or over $3 \%$, respectively. Robust heteroskedastic-consistent standard errors are reported in parenthesis below each coefficient estimate. Time fixed effects were included, but are not reported. Also a constant term has been estimated but it is not reported for reasons of parsimony. $* * *, * * *$ denote significance at 10,5 and $1 \%$ levels. 
Table 8a: Panel Granger-Causality - Private Investment and GDPpc (full sample)

\begin{tabular}{|c|c|c|c|c|c|c|}
\hline Dep.Var. private Inv. pc & OLS levels & Within Group (FE) & DIF-GMM & SYS-GMM & SYS-GMM-1 & SYS-GMM-2 \\
\hline Model & (1) & (2) & (3) & (4) & (5) & (6) \\
\hline Instrument set & none & none & Full & Full & Reduced & Reduced \\
\hline Lag1 priv_inv_pc & $\begin{array}{c}0.90 * * * \\
(0.052)\end{array}$ & $\begin{array}{l}0.35^{* * * *} \\
(0.132)\end{array}$ & $\begin{array}{c}0.30^{*} \\
(0.171)\end{array}$ & $\begin{array}{c}0.92 * * * \\
(0.107)\end{array}$ & $\begin{array}{l}1.06^{* * * *} \\
(0.083)\end{array}$ & $\begin{array}{l}0.99 * * * \\
(0.058)\end{array}$ \\
\hline Lag1 GDPpc & $\begin{array}{c}0.01 * \\
(0.004)\end{array}$ & $\begin{array}{c}0.02 * * * \\
(0.009)\end{array}$ & $\begin{array}{c}-0.02 \\
(0.019)\end{array}$ & $\begin{array}{c}0.01 \\
(0.005)\end{array}$ & $\begin{array}{c}0.00 \\
(0.003)\end{array}$ & $\begin{array}{c}0.00 \\
(0.004)\end{array}$ \\
\hline Obs. & 862 & 862 & 723 & 862 & 862 & 862 \\
\hline$R$-squared & 0.96 & 0.43 & & & & \\
\hline$A B A R(1)$ (p-value) & & & 0.96 & 0.00 & 0.00 & 0.00 \\
\hline$A B A R(2)$ (p-value) & & & 0.89 & 0.26 & 0.36 & 0.30 \\
\hline Hansen p-value & & & 0.09 & 0.12 & 0.01 & 0.02 \\
\hline Granger causality p-value & 0.06 & 0.01 & .00 & .05 & 0.00 & 0.00 \\
\hline LR effect point estimate & $.07 * * *$ & $.03 * * *$ & -.03 & $.07 *$ & -.01 & .31 \\
\hline (standard error) & $(.004)$ & $(.007)$ & $(.032)$ & $(.040)$ & $(.058)$ & 1.06 \\
\hline
\end{tabular}

Note: Our five-year averages dataset was used for the purpose of assessing Granger causality. Year dummies are included in all models (coefficients not reported). Figures in parenthesis below point estimates are standard-errors. The GMM results reported here are two-step estimates with heteroskedasticity-consistent standard errors. The Hansen test is used to assess the overidentifying restrictions; the test uses the minimized value of the corresponding two-step GMM estimator. The difference Hansen test is used to test the additional moment conditions used by the system GMM estimators in which SYS GMM uses the standard moment conditions, while SYS GMM-1 only uses the lagged first-differences of private investment dated t-2 (and earlier) as instruments in levels and SYS-2 only uses lagged first-differences of per capita GDP dated $\mathrm{t}-2$ (and earlier) as instruments in levels.. The Granger causality test examines the null hypothesis that private investment is not Granger-caused by per capita GDP; the test statistic is criterion based, using restricted and unrestricted models (see main text for details). The LR effect is the point estimate of the long-run effect of per capita GDP on private investment. Its standard error is approximated using the delta method. *, $* * * * *$ denote significance at 10,5 and $1 \%$ levels.

Table 8b: Panel Granger-Causality - GDPpc and Private Investment (full sample)

\begin{tabular}{|c|c|c|c|c|c|c|}
\hline Dep.Var. GDPpc & OLS levels & Within Group (FE) & DIF-GMM & SYS-GMM & SYS-GMM-1 & SYS-GMM-2 \\
\hline Model & (1) & (2) & (3) & (4) & (5) & (6) \\
\hline Instrument set & none & none & Full & Full & Reduced & Reduced \\
\hline Lag1 GDPpc & $\begin{array}{l}1.00 * * * \\
(0.007)\end{array}$ & $\begin{array}{c}0.84 * * * \\
(0.042)\end{array}$ & $\begin{array}{c}0.25^{*} \\
(0.129)\end{array}$ & $\begin{array}{c}0.96^{* * * *} \\
(0.032)\end{array}$ & $\begin{array}{c}0.97 * * * \\
(0.043)\end{array}$ & $\begin{array}{l}0.93 * * * \\
(0.027)\end{array}$ \\
\hline Lag1 priv_inv_pc & $\begin{array}{c}0.15 \\
(0.092)\end{array}$ & $\begin{array}{c}0.03 \\
(0.373)\end{array}$ & $\begin{array}{c}-0.03 \\
(0.540)\end{array}$ & $\begin{array}{l}1.60^{* * * *} \\
(0.508)\end{array}$ & $\begin{array}{l}1.66^{* *} \\
(0.816)\end{array}$ & $\begin{array}{l}1.70^{* * * *} \\
(0.547)\end{array}$ \\
\hline Obs. & 894 & 894 & 732 & 894 & 894 & 894 \\
\hline$R$-squared & 0.99 & 0.81 & & & & \\
\hline$A B A R(1)(p$-value) & & & 0.06 & 0.03 & 0.07 & 0.05 \\
\hline$A B A R(2)$ (p-value) & & & 0.65 & 0.00 & 0.00 & 0.00 \\
\hline Hansen p-value & & & 0.03 & 0.05 & 0.03 & 0.05 \\
\hline Granger causality p-value & 0.11 & 0.93 & 1.00 & .00 & 0.00 & 0.00 \\
\hline LR effect point estimate & $1.17 * * *$ & $.87 * * *$ & -.03 & $35.62 * *$ & 65.13 & $25.32 * * *$ \\
\hline (standard error) & $(.119)$ & $(.307)$ & $(.731)$ & $(17.063)$ & $(85.580)$ & $(4.981)$ \\
\hline
\end{tabular}

Note: See Table 8a. Mutatis mutandis. 
Table 9: Private and Public Investment equations with Government Expenditures and Revenues - accounting for Cross-Sectional Dependence, 5 year averages data - OECD

\begin{tabular}{|c|c|c|c|c|c|c|c|c|c|c|c|c|c|c|c|c|}
\hline \multirow{3}{*}{\begin{tabular}{|c|} 
Dep.Var. \\
Estimation \\
Model \\
\end{tabular}} & \multicolumn{8}{|c|}{ Private Investment } & \multicolumn{8}{|c|}{ Public Investment } \\
\hline & \multicolumn{4}{|c|}{ Discroll Kraay Robust Estimation } & \multicolumn{4}{|c|}{ CCEP } & \multicolumn{4}{|c|}{ Discroll Kraay Robust Estimation } & \multicolumn{4}{|c|}{ CCEP } \\
\hline & 1 & 2 & 3 & 4 & 6 & 7 & 8 & 9 & 11 & 12 & 13 & 14 & 16 & 17 & 18 & 19 \\
\hline Sample & \multicolumn{16}{|c|}{ OECD } \\
\hline inigdppe & $\begin{array}{c}-2.57^{* * *} \\
(0.225)\end{array}$ & $\begin{array}{c}-2.49 * * * \\
(0.189)\end{array}$ & $\begin{array}{c}-3.08 * * * \\
(0.073)\end{array}$ & $\begin{array}{c}-3.16^{* * *} \\
(0.098)\end{array}$ & $\begin{array}{c}-5.52^{* * *} \\
(1.010)\end{array}$ & $\begin{array}{c}-4.43 * * * \\
(0.982)\end{array}$ & $\begin{array}{c}-5.51 * * * \\
(1.521)\end{array}$ & $\begin{array}{c}-4.54 * * * \\
(0.978)\end{array}$ & $\begin{array}{c}-3.27 * * * \\
(0.564)\end{array}$ & $\begin{array}{c}-3.38 * * * \\
(0.526)\end{array}$ & $\begin{array}{c}-3.58^{* * *} \\
(0.450)\end{array}$ & $\begin{array}{c}-3.15^{* * *} \\
(0.546)\end{array}$ & $\begin{array}{l}3.82 * * \\
(1.613)\end{array}$ & $\begin{array}{l}4.26^{* *} \\
(1.590)\end{array}$ & $\begin{array}{c}3.20^{*} \\
(1.569)\end{array}$ & $\begin{array}{l}3.54 * * \\
(1.512)\end{array}$ \\
\hline Ifp & $\begin{array}{l}0.05 * * \\
(0.022)\end{array}$ & $\begin{array}{c}0.09^{* * *} \\
(0.013)\end{array}$ & $\begin{array}{c}0.15^{* * *} \\
(0.015)\end{array}$ & $\begin{array}{c}0.11^{* * *} \\
(0.021)\end{array}$ & $\begin{array}{l}0.19^{* *} \\
(0.089)\end{array}$ & $\begin{array}{l}0.20^{* *} \\
(0.088)\end{array}$ & $\begin{array}{c}0.34 * * * \\
(0.125)\end{array}$ & $\begin{array}{l}0.22 * * \\
(0.094)\end{array}$ & $\begin{array}{c}0.13 * * * \\
(0.027)\end{array}$ & $\begin{array}{c}0.13 * * * \\
(0.027)\end{array}$ & $\begin{array}{c}0.13^{* * *} \\
(0.013)\end{array}$ & $\begin{array}{l}0.10^{* * * *} \\
(0.024)\end{array}$ & $\begin{array}{c}0.18 \\
(0.227)\end{array}$ & $\begin{array}{c}0.16 \\
(0.205)\end{array}$ & $\begin{array}{c}0.27 \\
(0.212)\end{array}$ & $\begin{array}{c}0.19 \\
(0.231)\end{array}$ \\
\hline popgr & $\begin{array}{c}1.18 \\
(1.251)\end{array}$ & $\begin{array}{c}1.39 \\
(0.921)\end{array}$ & $\begin{array}{c}1.17^{* * *} \\
(0.138)\end{array}$ & $\begin{array}{l}1.69^{* * *} \\
(0.599)\end{array}$ & $\begin{array}{l}2.40 * * * \\
(0.611)\end{array}$ & $\begin{array}{c}2.26^{* * *} \\
(0.601)\end{array}$ & $\begin{array}{c}1.64^{*} \\
(0.876)\end{array}$ & $\begin{array}{l}2.24 * * * \\
(0.585)\end{array}$ & $\begin{array}{c}-0.10 \\
(0.501)\end{array}$ & $\begin{array}{c}0.14 \\
(0.408)\end{array}$ & $\begin{array}{c}-1.33 \text { *** } \\
(0.241)\end{array}$ & $\begin{array}{c}-0.56 \\
(0.589)\end{array}$ & $\begin{array}{c}2.32^{*} \\
(1.071)\end{array}$ & $\begin{array}{c}2.24^{*} \\
(1.025)\end{array}$ & $\begin{array}{c}2.24^{*} \\
(1.175)\end{array}$ & $\begin{array}{l}2.69^{*} \\
(1.266)\end{array}$ \\
\hline depratio_wa & $\begin{array}{l}-0.19^{* *} \\
(0.082)\end{array}$ & $\begin{array}{l}-0.20^{* *} \\
(0.085)\end{array}$ & $\begin{array}{c}-0.22 * * * \\
(0.072)\end{array}$ & $\begin{array}{c}-0.24 * * * \\
(0.075)\end{array}$ & $\begin{array}{l}-0.12 * * \\
(0.051)\end{array}$ & $\begin{array}{l}-0.10^{*} \\
(0.052)\end{array}$ & $\begin{array}{c}-0.08 \\
(0.068)\end{array}$ & $\begin{array}{l}-0.10^{*} \\
(0.053)\end{array}$ & $\begin{array}{c}-0.03 \\
(0.028)\end{array}$ & $\begin{array}{c}-0.03 \\
(0.029)\end{array}$ & $\begin{array}{c}-0.00 \\
(0.033)\end{array}$ & $\begin{array}{c}-0.02 \\
(0.028)\end{array}$ & $\begin{array}{l}0.14 * * \\
(0.058)\end{array}$ & $\begin{array}{l}0.13 * * \\
(0.055)\end{array}$ & $\begin{array}{c}0.13^{*} \\
(0.059)\end{array}$ & $\begin{array}{c}0.12^{*} \\
(0.059)\end{array}$ \\
\hline totgovrev_gdp & $\begin{array}{c}-0.09 \\
(0.058)\end{array}$ & & & & $\begin{array}{c}-0.14^{* * *} \\
(0.045)\end{array}$ & & & & $\begin{array}{c}0.04 * * * \\
(0.012)\end{array}$ & & & & $\begin{array}{c}-0.07 \\
(0.102)\end{array}$ & & & \\
\hline totgovexp_gdp & & $\begin{array}{c}-0.06 \\
(0.041)\end{array}$ & & & & $\begin{array}{c}-0.04 \\
(0.054)\end{array}$ & & & & $\begin{array}{c}0.07 * * * \\
(0.016)\end{array}$ & & & & $\begin{array}{c}-0.22 \\
(0.186)\end{array}$ & & \\
\hline totgovrevgr & & & $\begin{array}{c}71.03 * * * \\
(6.757)\end{array}$ & & & & $\begin{array}{l}32.28^{* *} \\
(15.294)\end{array}$ & & & & $\begin{array}{c}14.32 \\
(10.776)\end{array}$ & & & & $\begin{array}{c}4.09 \\
(21.336)\end{array}$ & \\
\hline totgovexpgr & & & & $\begin{array}{c}75.19 \\
(47.260)\end{array}$ & & & & $\begin{array}{c}34.46^{*} \\
(18.176)\end{array}$ & & & & $\begin{array}{c}10.95 \\
(11.140)\end{array}$ & & & & $\begin{array}{c}-20.11 \\
(35.996)\end{array}$ \\
\hline Obs. & 169 & 180 & 122 & 174 & 169 & 180 & 122 & 174 & 135 & 135 & 102 & 134 & 20 & 20 & 20 & 20 \\
\hline$R$-squared & 0.29 & 0.29 & 0.32 & 0.35 & 0.29 & 0.22 & 0.27 & 0.23 & 0.45 & 0.47 & 0.47 & 0.44 & 0.78 & 0.80 & 0.77 & 0.78 \\
\hline
\end{tabular}

Note: The models are estimated with either Driscoll Kraay robust estimator or the Pesaran's Common Correlated Effects Pooled estimator (CCPE) to correct for the existence of cross-sectional dependence in the OECD. The dependent variable is either private of public investment levels ( $\% \mathrm{GDP})$, as identified in the first row. Standard errors are reported in parenthesis below each coefficient estimate. A constant term has been estimated but it is not reported for reasons of parsimony. $*, * *, * * *$ denote significance at 10,5 and $1 \%$ levels. 
Table 10: Benchmark cross-country private investment equation and fiscal rules, 5-year averages

\begin{tabular}{|c|c|c|c|c|c|c|c|c|c|}
\hline Dependent Variable & \multicolumn{9}{|c|}{ Public Investment } \\
\hline Estimation & \multicolumn{9}{|c|}{ FE (within) } \\
\hline Sample & \multicolumn{9}{|c|}{ EU } \\
\hline Spec. & 1 & 2 & 3 & 4 & 5 & 6 & 7 & 8 & 9 \\
\hline Equation & \multicolumn{3}{|c|}{$I .2$} & \multicolumn{3}{|c|}{ I.2<60\%debt to GDP ratio } & \multicolumn{3}{|c|}{ I.2>60\%debt to GDP ratio } \\
\hline l.real GDPpc & $\begin{array}{c}0.31^{*} \\
(0.151)\end{array}$ & $\begin{array}{c}0.12 \\
(0.188)\end{array}$ & $\begin{array}{l}0.35 * * \\
(0.132)\end{array}$ & $\begin{array}{c}0.34 * \\
(0.130)\end{array}$ & $\begin{array}{c}0.32 * \\
(0.116)\end{array}$ & $\begin{array}{c}0.39 * \\
(0.165)\end{array}$ & $\begin{array}{c}0.29 \\
(0.213)\end{array}$ & $\begin{array}{c}-0.04 \\
(0.278)\end{array}$ & $\begin{array}{c}0.29 \\
(0.200)\end{array}$ \\
\hline Ifp & $\begin{array}{c}0.02 * \\
(0.009)\end{array}$ & $\begin{array}{l}0.02 * * \\
(0.009)\end{array}$ & $\begin{array}{c}0.01 \\
(0.008)\end{array}$ & $\begin{array}{l}0.02 * * \\
(0.006)\end{array}$ & $\begin{array}{l}0.02 * * \\
(0.007)\end{array}$ & $\begin{array}{c}0.02 * \\
(0.008)\end{array}$ & $\begin{array}{c}-0.00 \\
(0.011)\end{array}$ & $\begin{array}{c}0.01 \\
(0.013)\end{array}$ & $\begin{array}{l}-0.00 \\
(0.012)\end{array}$ \\
\hline popgr & $\begin{array}{c}0.02 \\
(0.030)\end{array}$ & $\begin{array}{c}0.02 \\
(0.034)\end{array}$ & $\begin{array}{c}0.03 \\
(0.028)\end{array}$ & $\begin{array}{c}-0.04 \\
(0.044)\end{array}$ & $\begin{array}{c}-0.05 \\
(0.050)\end{array}$ & $\begin{array}{c}-0.01 \\
(0.040)\end{array}$ & $\begin{array}{l}0.06 * * \\
(0.022)\end{array}$ & $\begin{array}{l}0.05^{* *} \\
(0.016)\end{array}$ & $\begin{array}{l}0.07 * * \\
(0.022)\end{array}$ \\
\hline depratio_wa & $\begin{array}{c}-0.01 * * \\
(0.006)\end{array}$ & $\begin{array}{l}-0.02 * * \\
(0.006)\end{array}$ & $\begin{array}{c}-0.01 * * * \\
(0.004)\end{array}$ & $\begin{array}{c}-0.00 \\
(0.004)\end{array}$ & $\begin{array}{c}-0.00 \\
(0.005)\end{array}$ & $\begin{array}{c}-0.01 \\
(0.005)\end{array}$ & $\begin{array}{l}-0.02 * * \\
(0.008)\end{array}$ & $\begin{array}{l}-0.03 * * \\
(0.009)\end{array}$ & $\begin{array}{l}-0.02 * * \\
(0.007)\end{array}$ \\
\hline fisrulov & $\begin{array}{l}-0.03 * \\
(0.015)\end{array}$ & & & $\begin{array}{c}-0.02 \\
(0.012)\end{array}$ & & & $\begin{array}{l}-0.04 * \\
(0.021)\end{array}$ & & \\
\hline exprulov & & $\begin{array}{c}0.01 \\
(0.011)\end{array}$ & & & $\begin{array}{c}-0.01 \\
(0.008)\end{array}$ & & & $\begin{array}{c}0.05 \\
(0.034)\end{array}$ & \\
\hline bbdrulov & & & $\begin{array}{c}-0.05^{* *} \\
(0.016)\end{array}$ & & & $\begin{array}{c}-0.03 \\
(0.021)\end{array}$ & & & $\begin{array}{c}-0.05^{* *} \\
(0.017)\end{array}$ \\
\hline Obs. & 210 & 210 & 210 & 75 & 75 & 75 & 135 & 135 & 135 \\
\hline$R$-squared & 0.48 & 0.44 & 0.52 & 0.62 & 0.62 & 0.61 & 0.51 & 0.48 & 0.54 \\
\hline
\end{tabular}

Note: The models are estimated by Within Fixed Effects (FE-within) The dependent variable is public investment,. Robust heteroskedastic-consistent standard errors are reported in parenthesis below each coefficient estimate. A constant term has been estimated but it is not reported for reasons of parsimony. *, **, *** denote significance at 10,5 and $1 \%$ levels. 


\section{Appendix A - Variables and sources}

Table A1 - Variable definitions

\begin{tabular}{|c|c|c|c|}
\hline Variable & Definition/Description & Acronym & Source \\
\hline real GDP per capita & & Gdppc & $\begin{array}{l}\text { World Bank's Word } \\
\text { Development Indicators } \\
\text { (WDI) }\end{array}$ \\
\hline $\begin{array}{l}\text { gross fixed capital formation }(\% \\
\text { GDP) }\end{array}$ & & $G f c f \_d p$ & WDI \\
\hline public investment (\% GDP) & & Pubinv gdp & WDI \\
\hline $\begin{array}{l}\text { Government budget surplus or } \\
\text { deficit (\% of GDP) }\end{array}$ & The government budget surplus or deficit as a percentage of GDP. & Govbal_gdp & $\begin{array}{l}\text { WDI, IMF IFS, Easterly } \\
(2001)\end{array}$ \\
\hline $\begin{array}{l}\text { Central Government Debt }(\% \\
\text { GDP) }\end{array}$ & & Govdebt_gdp & $\begin{array}{l}\text { WDI, IMF IFS, Easterly } \\
\text { (2001) }\end{array}$ \\
\hline $\begin{array}{l}\text { Total Government Revenue }(\% \\
\text { GDP) }\end{array}$ & Total government revenue, excluding grants, as a percentage of GDP & Totgovrev_gdp & $\begin{array}{l}\text { WDI, IMF IFS, Easterly } \\
(2001)\end{array}$ \\
\hline Tax revenue (\% GDP) & & Taxrev_gdp & $\begin{array}{l}\text { WDI, IMF IFS, Easterly } \\
(2001)\end{array}$ \\
\hline $\begin{array}{l}\text { Domestic taxes on goods and } \\
\text { services (\% GDP) }\end{array}$ & This includes VAT, excises, profits of fiscal monopoly etc. & Domtaxesgs_gdp & $\begin{array}{l}\text { WDI, IMF IFS, Easterly } \\
\text { (2001) }\end{array}$ \\
\hline $\begin{array}{l}\text { Taxes on payroll or work force } \\
\text { (\% of GDP) }\end{array}$ & $\begin{array}{l}\text { This category consists of taxes that are collected from employers or the self- } \\
\text { employed and that are not earmarked for social security schemes. }\end{array}$ & Taxpayrool_gdp & $\begin{array}{l}\text { WDI, IMF IFS, Easterly } \\
(2001)\end{array}$ \\
\hline $\begin{array}{l}\text { Taxes on income, profits and } \\
\text { capital gains }(\% \text { GDP) }\end{array}$ & Taxes on income, profits and capital gains as a percentage of GDP. & Taxincome_gdp & $\begin{array}{l}\text { WDI, IMF IFS, Easterly } \\
(2001)\end{array}$ \\
\hline Taxes on property (\% of GDP) & Taxes on the use, ownership, or transfer of wealth & Taxproperty_gdp & $\begin{array}{l}\text { WDI, IMF IFS, Easterly } \\
(2001)\end{array}$ \\
\hline $\begin{array}{l}\text { Tax and social security } \\
\text { contributions government } \\
\text { revenue }(\% \text { of } \\
\text { GDP) }\end{array}$ & Total government revenue from taxes and social security contributions & Taxssgovrev_gdp & $\begin{array}{l}\text { WDI, IMF IFS, Easterly } \\
(2001)\end{array}$ \\
\hline $\begin{array}{l}\text { Total Government Expenditure } \\
(\% \text { GDP) }\end{array}$ & Total government expenditure as a percentage of GDP. & Totgovexp_gdp & $\begin{array}{l}\text { WDI, IMF IFS, Easterly } \\
(2001)\end{array}$ \\
\hline $\begin{array}{l}\text { Compensation of employees (\% } \\
\text { GDP) }\end{array}$ & & Govexpwages_gdp & $\begin{array}{l}\text { WDI, IMF IFS, Easterly } \\
(2001)\end{array}$ \\
\hline Interest Payments (\% GDP) & & Inpay_gdp & $\begin{array}{l}\text { WDI, IMF IFS, Easterly } \\
\text { (2001) }\end{array}$ \\
\hline Subsidies (\% GDP) & & Subs_gdp & $\begin{array}{l}\text { WDI, IMF IFS, Easterly } \\
(2001)\end{array}$ \\
\hline $\begin{array}{l}\text { Public Final Consumption } \\
\text { Expenditure }(\% \text { GDP) }\end{array}$ & & Govcons_gdp & $\begin{array}{l}\text { WDI, IMF IFS, Easterly } \\
(2001)\end{array}$ \\
\hline $\begin{array}{l}\text { Public spending on Education } \\
\text { (\% GDP) }\end{array}$ & Government expenditure on education as a percentage of GDP. & Govexpedu_gdp & $\begin{array}{l}\text { WDI, IMF IFS, Easterly } \\
(2001)\end{array}$ \\
\hline $\begin{array}{l}\text { Public spending on Health (\% } \\
\text { GDP) }\end{array}$ & Government expenditure on health as a percentage of GDP. & Govexphea_gdp & $\begin{array}{l}\text { WDI, IMF IFS, Easterly } \\
(2001)\end{array}$ \\
\hline $\begin{array}{l}\text { Public spending on Social } \\
\text { Security and Welfare related (\% } \\
\text { GDP) }\end{array}$ & $\begin{array}{l}\text { Government expenditure on social security and welfare as a percentage of } \\
\text { GDP. }\end{array}$ & Govexpss_gdp & $\begin{array}{l}\text { WDI, IMF IFS, Easterly } \\
\text { (2001) }\end{array}$ \\
\hline School attainment & $\begin{array}{l}\text { average years of schooling in the population over } 25 \text { years old from the } \\
\text { international data on educational attainment }\end{array}$ & $E d u$ & Barro and Lee (2010) \\
\hline $\begin{array}{l}\text { literacy rate }(\% \text { of people ages } \\
15 \text { to } 24)\end{array}$ & & Literates & WDI \\
\hline $\begin{array}{l}\text { primary school enrolment }(\%) \\
\text { gross })\end{array}$ & & Primary_enrol & WDI \\
\hline primary school duration (years) & & Primary_dur & WDI \\
\hline $\begin{array}{l}\text { secondary school enrolment }(\% \\
\text { gross) }\end{array}$ & & Secondaru_enrol & WDI \\
\hline $\begin{array}{l}\begin{array}{l}\text { secondary } \\
\text { (years) }\end{array} \\
\text { school duration } \\
\end{array}$ & & Secondary_dur & WDI \\
\hline $\begin{array}{l}\begin{array}{l}\text { tertiary } \\
\text { gross })\end{array} \\
\text { school enrolment } \quad(\% \\
\end{array}$ & & Tertiary_enrol & WDI \\
\hline tertiary school duration (years) & & Tertiary_dur & WDI \\
\hline land area (in square kilometres) & & Land_area & WDI \\
\hline population & & Pop & WDI \\
\hline $\begin{array}{l}\text { imports and exports of good and } \\
\text { services (BoP, current USD) }\end{array}$ & & Imp, exp & WDI \\
\hline $\begin{array}{l}\text { labor participation rate }(\% \text { of } \\
\text { total) }\end{array}$ & & $L f p$ & WDI \\
\hline labor force & & Laborf & WDI \\
\hline $\begin{array}{l}\text { unemployment, total (\% of total } \\
\text { labor force) }\end{array}$ & & Unemp & WDI \\
\hline fertility rate (births per woman) & & Fertility & WDI \\
\hline $\begin{array}{l}\text { age dependency ratio }(\% \text { of } \\
\text { working age population) }\end{array}$ & & Depratio_wa & WDI \\
\hline urban population (\% of total) & & Urban pop & WDI \\
\hline $\begin{array}{l}\text { terms of trade adjustment } \\
\text { (constant LCU) }\end{array}$ & & Terms_trade & WDI \\
\hline $\begin{array}{l}\text { real effective exchange rate } \\
\text { index }(2000=100)\end{array}$ & & Reer & WDI \\
\hline
\end{tabular}




\section{Appendix B}

Table B1: Benchmark cross-country investment equations, 5-year averages (including time period dummies) - LSDV-C

\begin{tabular}{|c|c|c|c|c|c|c|}
\hline \multirow{3}{*}{$\begin{array}{c}\text { Dependent Variable } \\
\text { Estimation } \\
\text { Sample }\end{array}$} & \multicolumn{3}{|c|}{ Private Investment } & \multicolumn{3}{|c|}{ Public Investment } \\
\hline & \multicolumn{6}{|c|}{ LSDV-C } \\
\hline & All & OECD & Emerg & All & OECD & Emerg \\
\hline Spec. & 1 & 2 & 3 & 4 & 5 & 6 \\
\hline Equation & & $I .1$ & & & $I .2$ & \\
\hline inigdppc & $\begin{array}{c}-3.40 * * * \\
(0.663)\end{array}$ & $\begin{array}{c}-2.72 * * * \\
(0.884)\end{array}$ & $\begin{array}{c}2.01 \\
(1.307)\end{array}$ & $\begin{array}{c}0.04 \\
(0.867)\end{array}$ & $\begin{array}{c}-0.16 \\
(0.523)\end{array}$ & $\begin{array}{c}2.44^{*} \\
(1.347)\end{array}$ \\
\hline Ifp & $\begin{array}{c}-0.04 \\
(0.060)\end{array}$ & $\begin{array}{c}0.08 \\
(0.071)\end{array}$ & $\begin{array}{c}-0.03 \\
(0.100)\end{array}$ & $\begin{array}{c}0.02 \\
(0.074)\end{array}$ & $\begin{array}{c}0.05 \\
(0.049)\end{array}$ & $\begin{array}{c}0.05 \\
(0.103)\end{array}$ \\
\hline popgr & $\begin{array}{c}1.46 * * * \\
(0.227)\end{array}$ & $\begin{array}{c}2.51 * * * \\
(0.529)\end{array}$ & $\begin{array}{l}1.44 * * * \\
(0.398)\end{array}$ & $\begin{array}{c}0.49^{*} \\
(0.249)\end{array}$ & $\begin{array}{l}1.01 * * * \\
(0.275)\end{array}$ & $\begin{array}{c}-0.32 \\
(0.855)\end{array}$ \\
\hline depratio_wa & $\begin{array}{c}-0.09 * * * \\
(0.024)\end{array}$ & $\begin{array}{c}-0.12^{* * * *} \\
(0.039)\end{array}$ & $\begin{array}{c}-0.01 \\
(0.049)\end{array}$ & $\begin{array}{c}0.08^{* * * *} \\
(0.030)\end{array}$ & $\begin{array}{c}0.03 \\
(0.023)\end{array}$ & $\begin{array}{l}0.19 * * * \\
(0.053)\end{array}$ \\
\hline Obs. & 980 & 202 & 193 & 479 & 146 & 98 \\
\hline
\end{tabular}

Note: The models are estimated with Brunos' (2005) Least Squares Dummy Variable (corrected) estimator. The dependent variable is either private investment or public investment,. Robust heteroskedastic-consistent standard errors are reported in parenthesis below each coefficient estimate. A constant term has been estimated but it is not reported for reasons of parsimony. $*, * *, * * *$ denote significance at 10,5 and $1 \%$ levels. 